( 785$)$



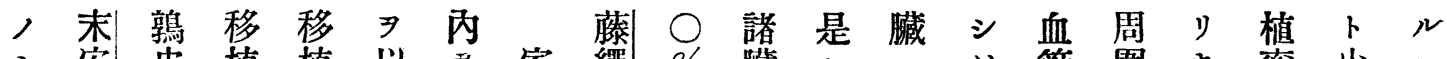
ミ 安留, 植植 以

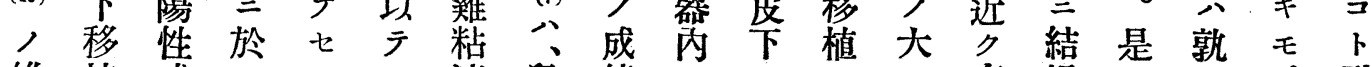
雉植成ケル七液鼠績三人,

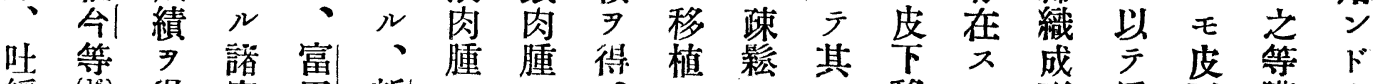

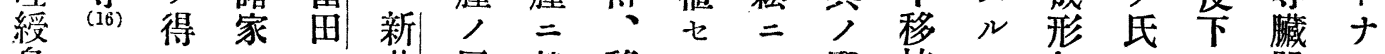

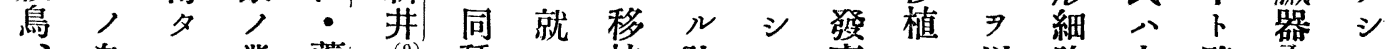

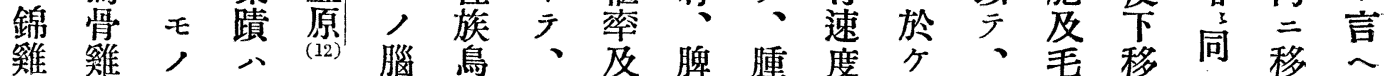

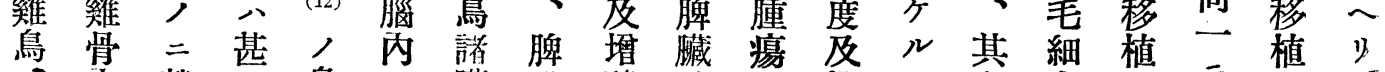

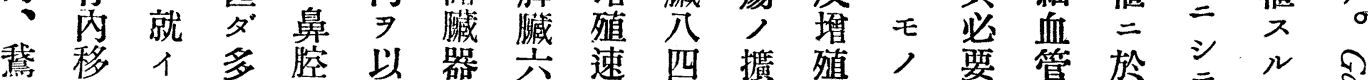

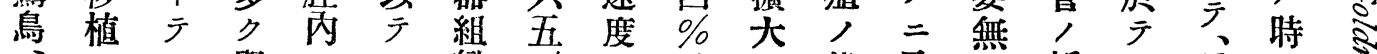
家於、舆

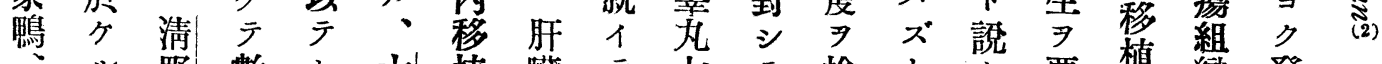
舀 寞

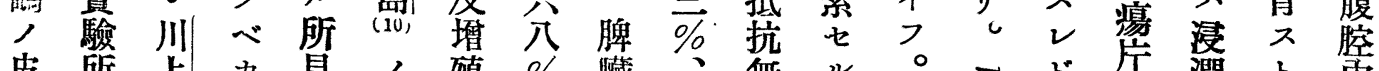

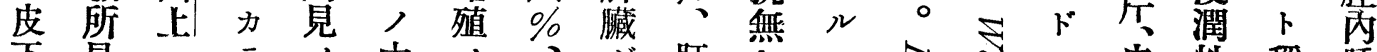

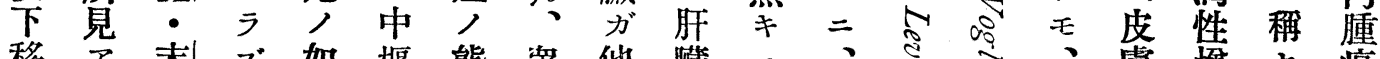

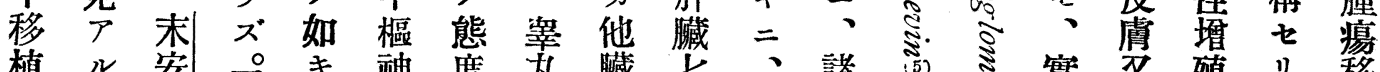

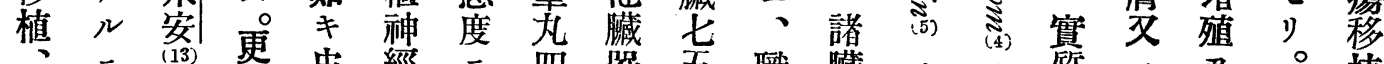

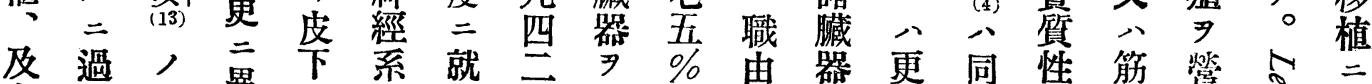
島 ズ 华種 外、 (17) 吕鳥族 $尹$ 腹研腎 家陰卯植培腔究藏ル六明腫肉腫移管皮、腫

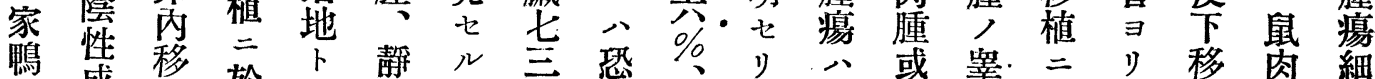

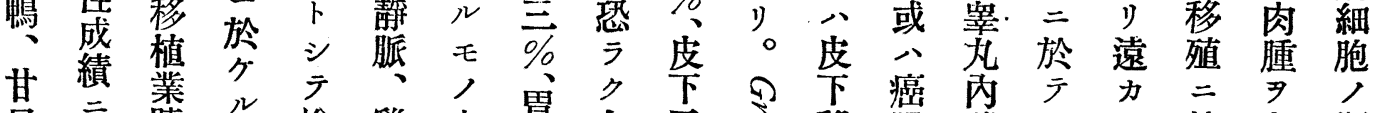

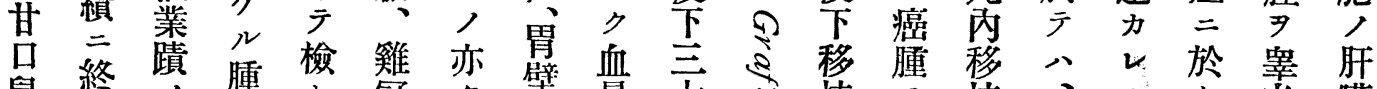

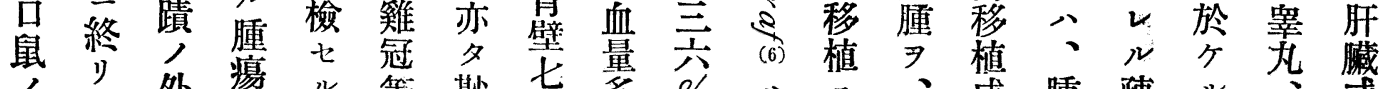

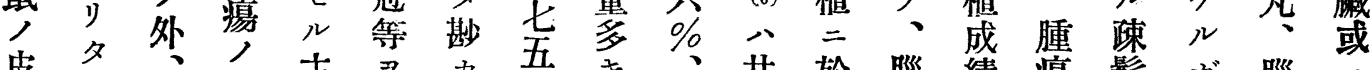

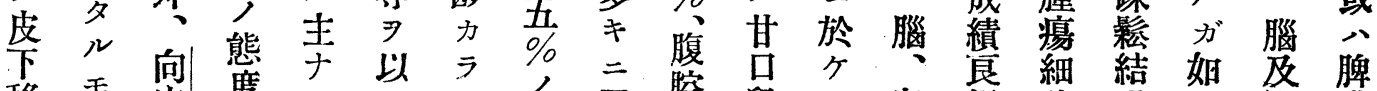

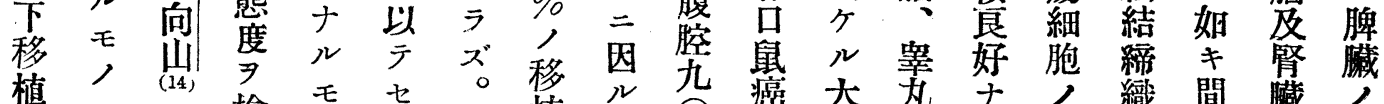

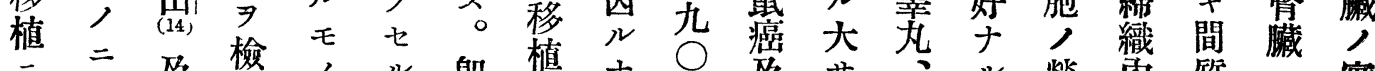
對 就清索 ナ ス

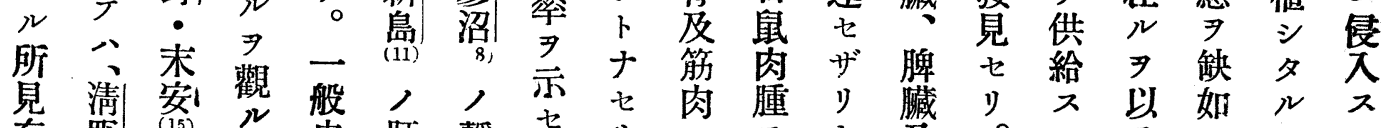
筫清| 悹野 有野 
タリ。妹 績

○佾 金 終 緼

乃皮腹学肉

チ下、し 是少

等 腹 や 報 鳴 類腔が告 禽

第

筋 \begin{tabular}{ccc} 
& 七 & 類 \\
\hline
\end{tabular} 諸惯紅 然

節 地筋 雀 試 二内、 於等雀著 夕 ケ三等者 ル 移抆少曾 植モク驗、

鳥堌 全 $モ$ 調 著 殖然无調都 態可代ル 前 度能文二、倩 检释多移二 七 ス 植林 ルハ竞 氐 所 $=$ 八地 ${ }^{(20)}$

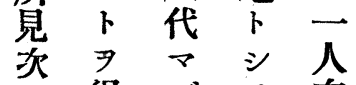
人 得 デテ有 如 $x^{-}$一筋,

。或 ○肉 程 \% $\%$ 而

度分探 モ

移儿氏

デ植 特 八

コ陽 、雀

、性、了

二成鳴，皮

モ 績 禽 下

賭 $尹$ 類 二

大得登移

笲コ烄 シ

ス卜鳥 テ

明 陰

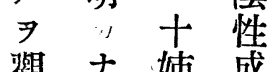

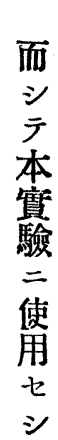

材

料

鶲

類 鳥

植家

增 䌖

殖䳋

態 二

度 於

次

外

ス

ヘ

テ

前

回

二

報

告

せ

同

材

料

$=$

$\exists$

ข

リ
テ 移

移其凛 、二

腫 一 夙

リ演

定邊 彩

㙕 長 部 二 特 料

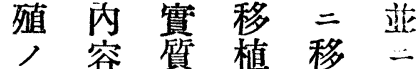

態 細 七 植 廂

度目胞 ラ腫 驗

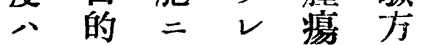

肉部富

的二ッリ及二

及选 部二移 第

組 致 分 週 植 回

織七业間培回

學”。制内地及

的移離 外 、第

屠移淔 細 經 全 畐

杀部截過珙塟

死位 シ 并驗 告

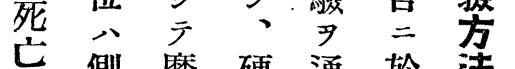

七 惻糜硬通於

ル部牀軟テテル

或 $ト$ 部

こ一ナ過及,

二大柴的二

日腿、

3 側

逐部徑 圣條。

队徑

筋 $\overrightarrow{\neq} \neq$ 天

檢肉粍二下腫

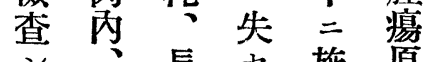

筋長七゙施原

、肋サザ 行 株

天 胃

サ 筋

粧程り

藤

人, 郎・

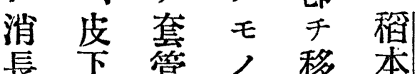

公針ナ植系

の腹二リ二家

に腔充。供雞

う等 盈力 ス 粘

寸于盛、ル液

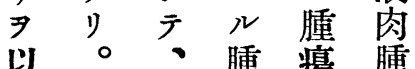

等 堌 第・

腹 殖

岗態及自

满蔵 度 第・显

器 $\exists$ 三

二、報・家

第 管 少 靠! 䌖

第二洨

一 廣 記 肉

覃ノ沉述腫

及細 成

實 ビ二所熟

験 懟 攻 $P$ 異

材照究り種

科卜七。族

前 シ ン 藷鳥

テ卜 者 特

v。更鳴

而二禽

家 シ 家 類

雞 テ 雞 及

當本粘 䲴

該 報 液 類

培 告 肉筋

地 八腫 肉

二筋, 队

於因一移

ケ內般植

及成二

習皮熟成

殖 下 異 功

所二種七

見於族り

尔動。

モル物而

加 所 諸 シ

一見藏 テ

夕 $\exists$ 器 移

り主組植

織成

、於就

佾ケ大

筋 ル 要

胃筇移既

肉植 二 


\section{究研的敛贯, 腫肉雉家}

(788)

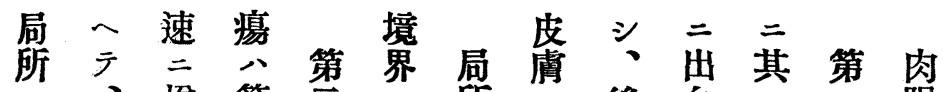

二 增 第 严公所 後 血公 眼

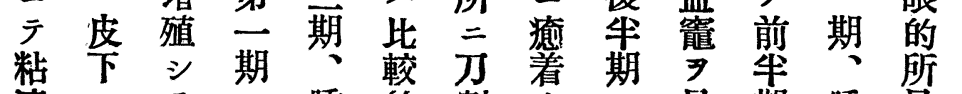

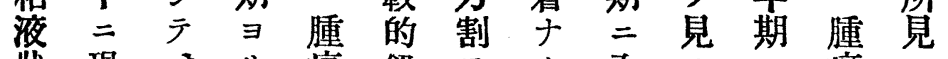

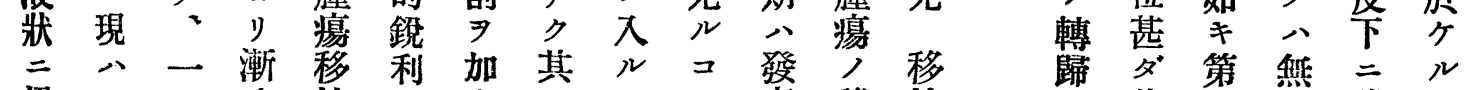

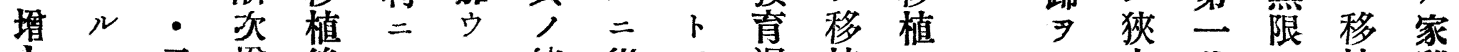

大、云增後 シ ル 岱從ア幄植セ

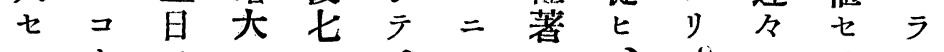

俩,

卜 小代 二 植 雞

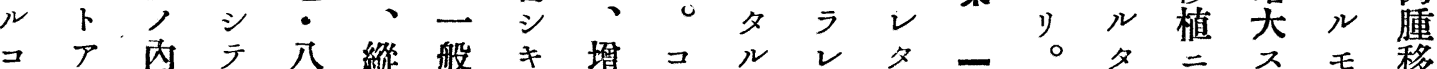

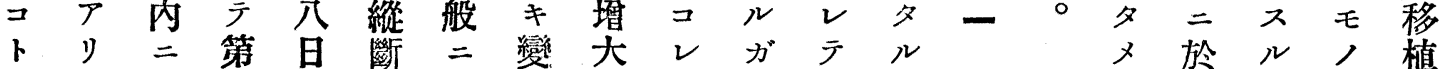

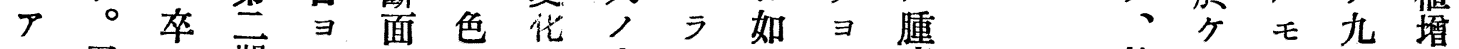

》。忠只期り

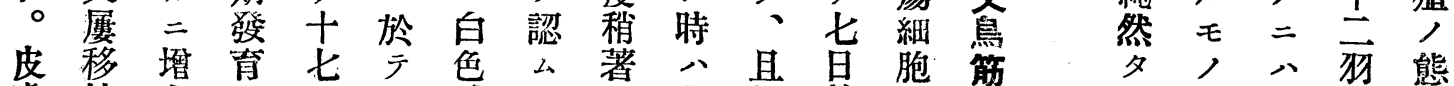

虞植大

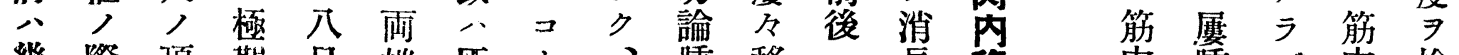

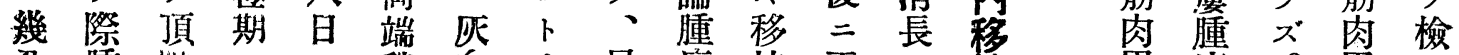

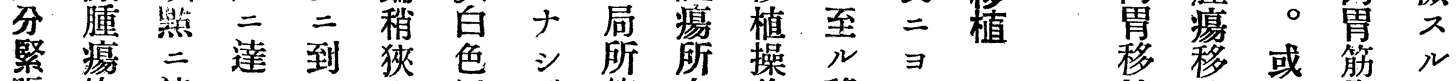

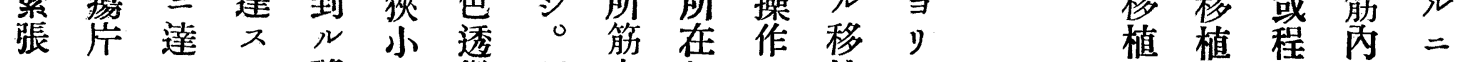

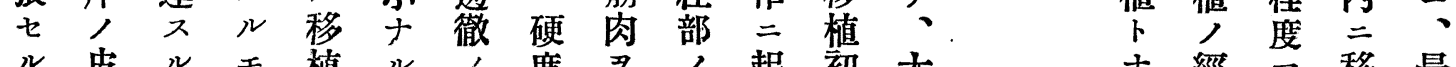

ル皮ルモ植ル人度妇起初大經、移最

モ下コノ中コ敬

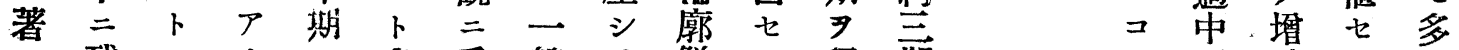

シ 残アリシ多乏般テ蘚ル 稱 期

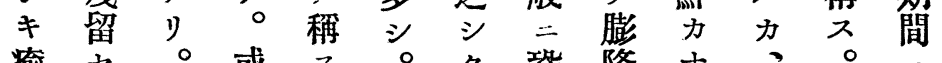

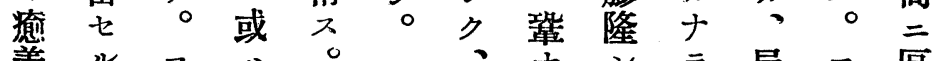

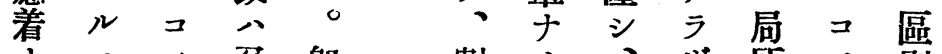

ナモノ爻䬦割り、ザ所、ノ別

シノ期甚于面。輪ル皮時ス

、多腫疎廓

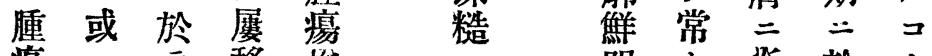

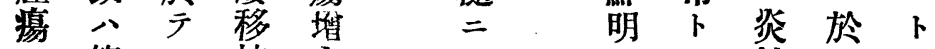

尹 筋 八 植 大

外肉腫後㕣方。浮八得

壁內場七頂滑りカ腫移心゙

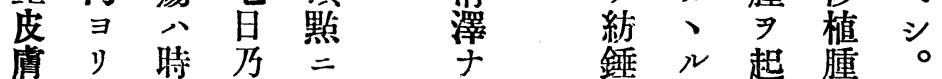

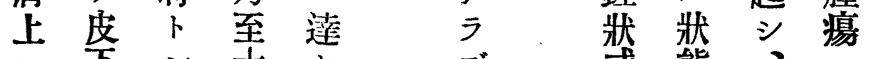

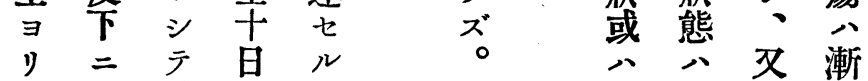

塺溢被前時周 索 日時次

ス出覆後期園牀占卜堵

$\sim 七$ 筋

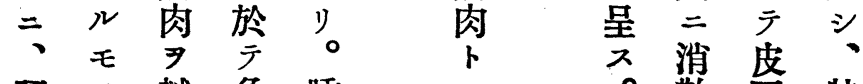

硬, 越急腫, ○散每特

卜 死 殖ル ク

能乞 七モ 使

八スル人角

ズル 時 †

常卜自须一

二小然文

腹り 計鳥

膑。縮百ナ

內特小岿り。

溢筋收狗 。

出肉七り

增胃 。本

大 筋 ル 文 實

シ 芮、鳥 驗

云 モ

ב移, 移行

ノ植ナ植 フ

時七り七夕

交ル。广

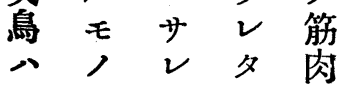


( 789 )

\begin{tabular}{llll} 
述 $\quad$ - 松 & 赤 \\
\hline
\end{tabular}

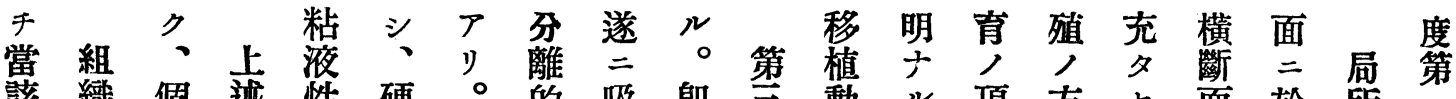

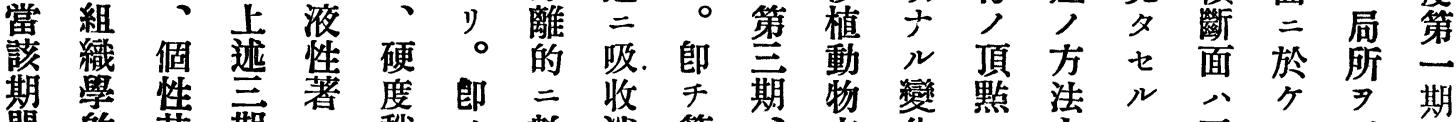

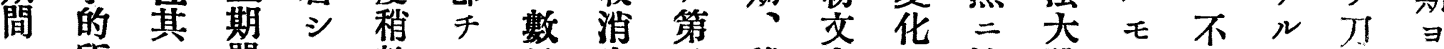

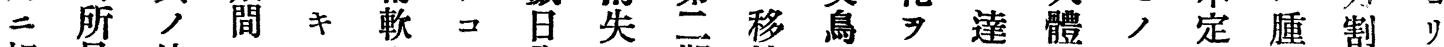

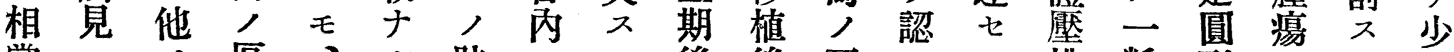
當入區、ル時三ル後後死么ル排粍形儿ハシ

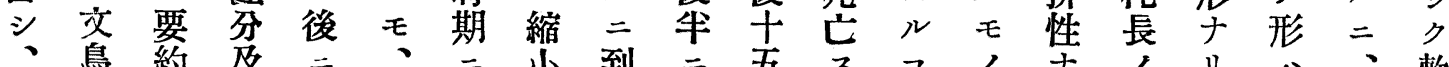
組 筋 二 各 變 縮 於 シ 到 織愈

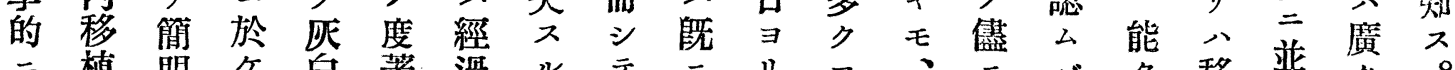
检植 盟ケ白著過 ル武 檢 腫 單

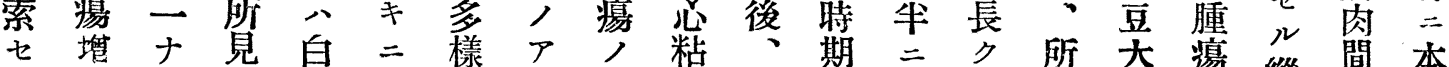

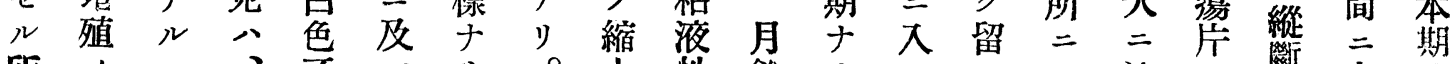

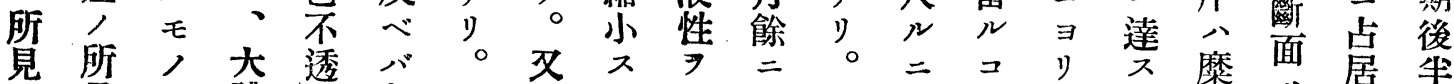

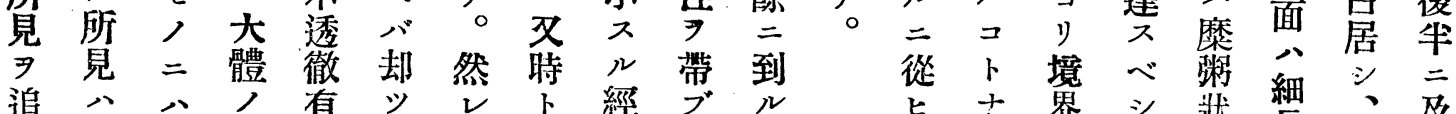
追、ハ人經有形デド 䚿大 ラ 經 形 テ ド シ 過 ル 縮

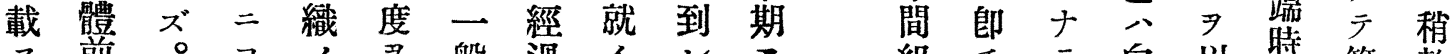

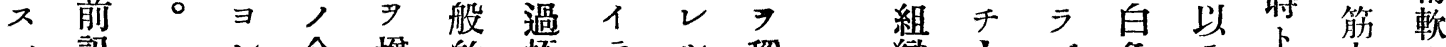

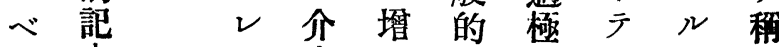

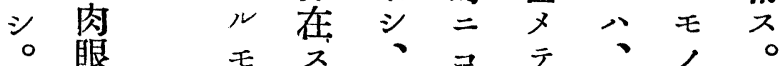

的 $ノ$ 再 $v$ 紱多、 所 =

見 シ 觀 腪 觀 二

$=$ テ トレシ漸期二

ヨ、コナ゙テテ進文於

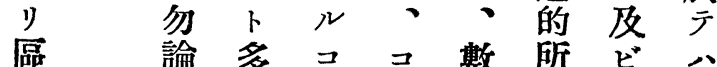

分其 シ 卜, 妓謂テ腫

七分。多期日分 、癔

時間機初後的腫變

期多割 $x$ 初

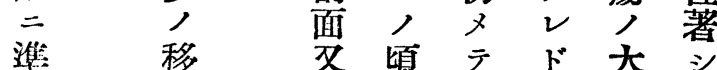

ジ行之吸、ササ

テ 三大收時著、

終變 凖サ サ卜 明縮

始 狀 济モル

ス 厂初相、テ縮 吸

乃 バ メ 當モ急小收

織大

强サ、或、莳屓ル

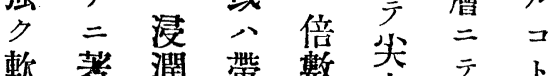

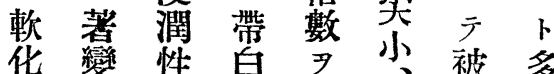
化變性自买少被多 テク 八筋テ體皆。 粘、破肉表占亏

液性壞卜少 シ 性筫性, ステ、 著的ナ境 コ筋 ガ シ $=ル$ 界卜肏如 クモ尹 、難繊キ ナコ思比ケ 維 觀 ルノ八較レノア コ 期 $三$ 的 $F^{\circ}$ 走呈 前么 明內 向 多半ル瞭徑方ル シ三モナ向モ ○於ノり粍二人 而广ア。套介ア シ 、リ。郎管在り。 被著發增 


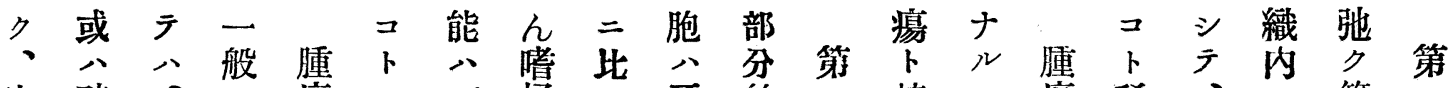

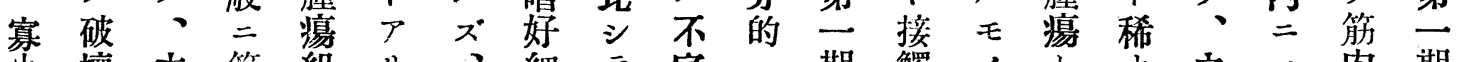

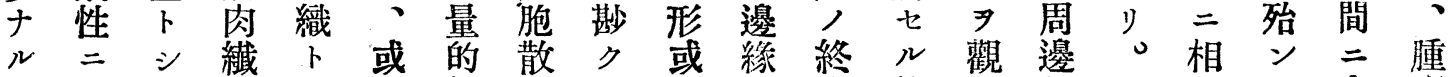

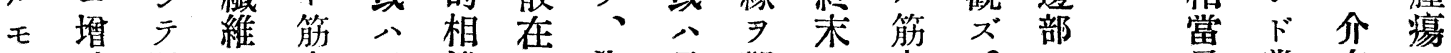

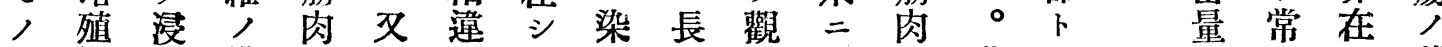

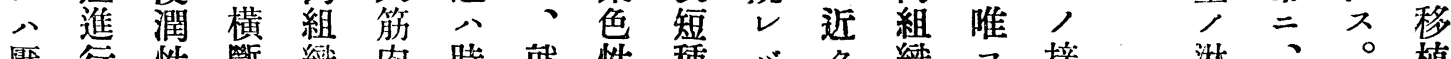
壓行 性斷織肉時就性種 バク織コ接淋、植 排七

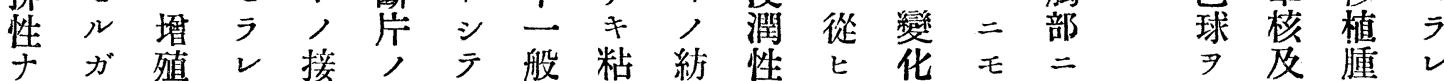
如 シ タ 觸遺有 ガキ、ル部殘之假組形、、、ク假份、加核、、



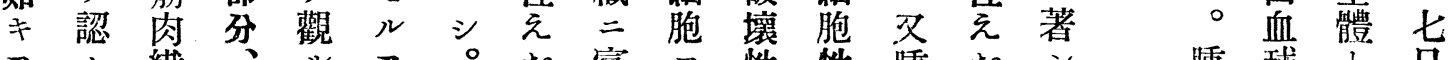

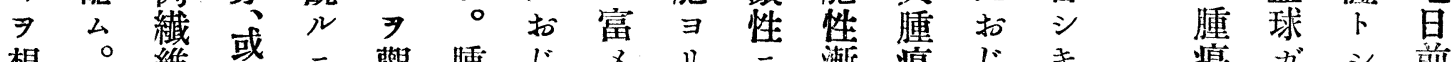

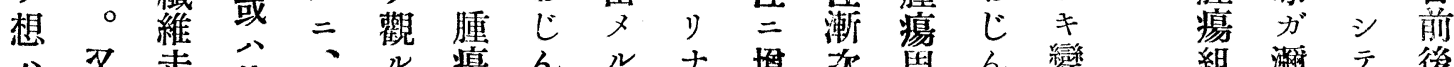

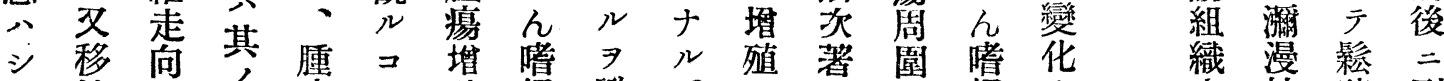

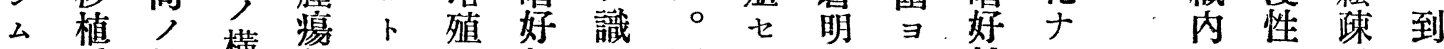

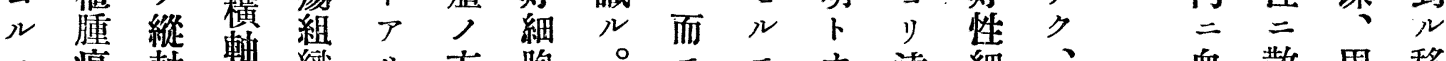

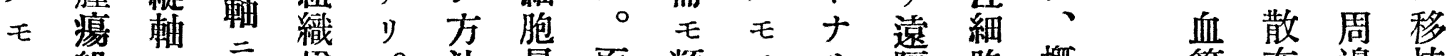
厂 組 二 對垻。法最而類, ’隔胞概 管 在邊植

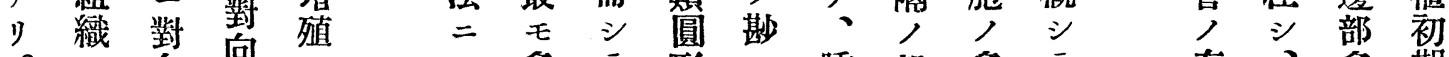
向向当多テ形力腫部多テ

性七七方止腫幼

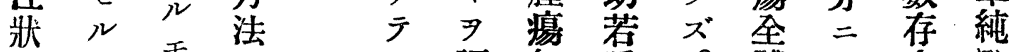

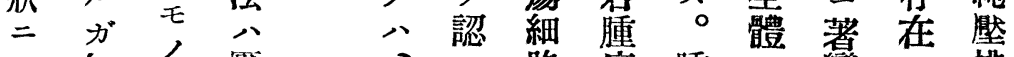

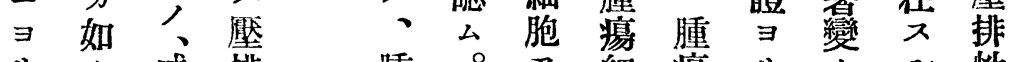

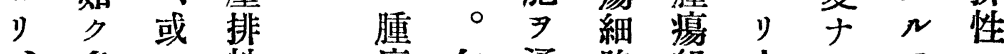

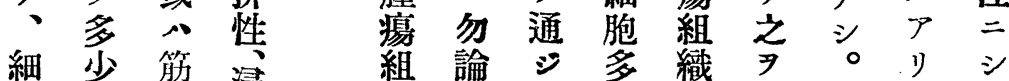

胞分間 浸 豊 抵 血 性 ナ, 所 破 $ル$ 存 在 壇 部 ス 部性

分, 交

、部如 今

浸分手: 存

潤二筙 ス

性 向 蹯 ル

破采当

壤 テ 部 認

性、分么

ナ壓 二 べ

ル排向ク、
織論主

內等、存殆 等、、

二細 單 在 ソ バ更結

血 胞 核七ド概 二 締

管人白儿全不淋織

存割血一般 壓

立 合 球邊 三排

シ 一淋緣 宣 性

赤樣 巴 シ テ 增

血三球テ、瀷大

球論、、殖 ス



盈ル元部腫如

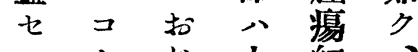

巴

球 塤

加生

八 血管

ル

马 新

認 生

么 等

腫明
存、多期

ス特 少ナ

ル = 細り

a $=$ 胞

卜分性

比期二,

較二富期

的於又,

卙テル前

ク假 ガ年

、性 如 二

筋元 $\neq$ 於

肉おモテ

組し、、

織ん而

ノ嘹モ一

遺 好著 般

殘 性 明二

䈟細于堽

入胞 ラ 殖

七頗 ズノ

ルル。踈

ガ豊 腫 少

如富癔 ク 


\section{二血混圓二而分，分中，密 $v$ 化}

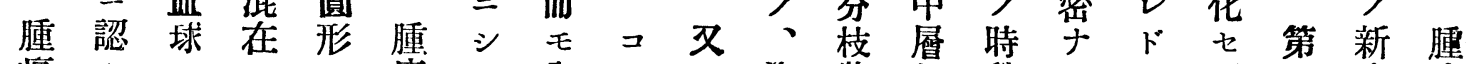

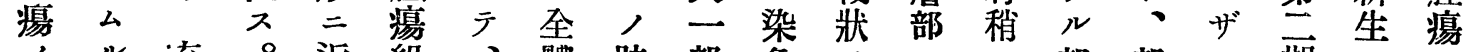

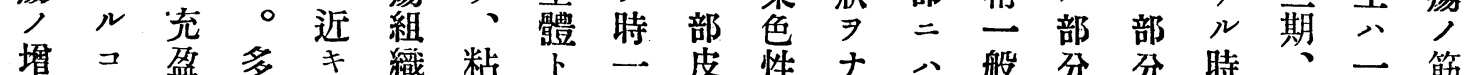
殖卜 会數 腫

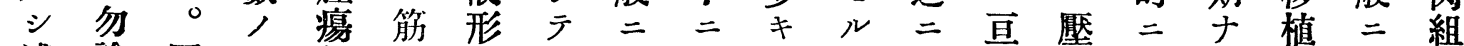

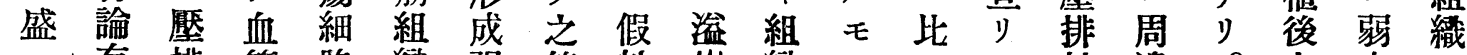
二有排管胞織强等性出織, ステ性邊。七少卜

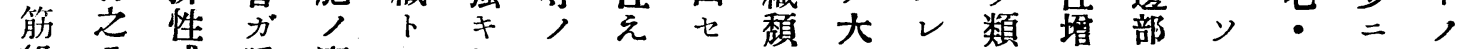

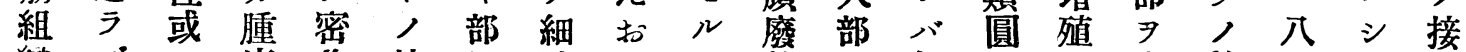

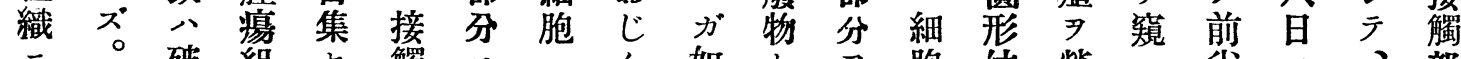

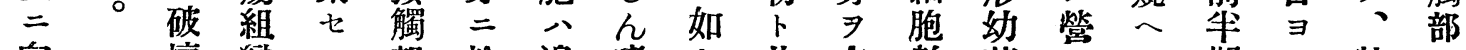

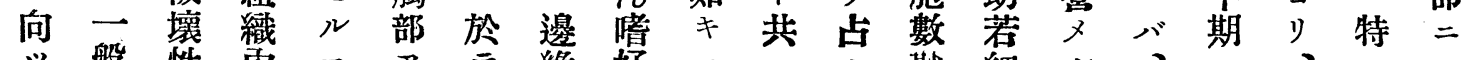

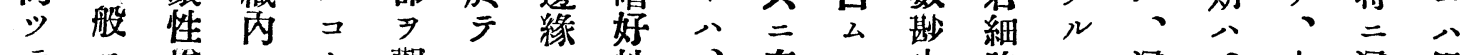

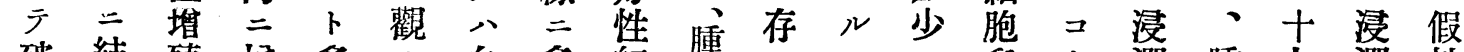

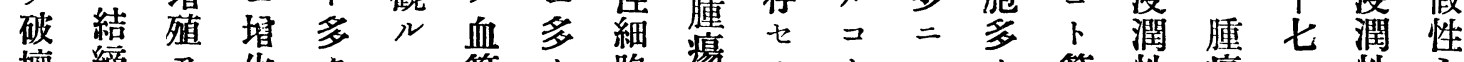

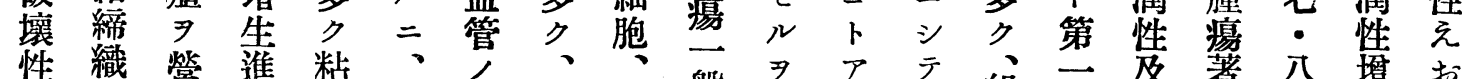
性 織 營 進 粘、

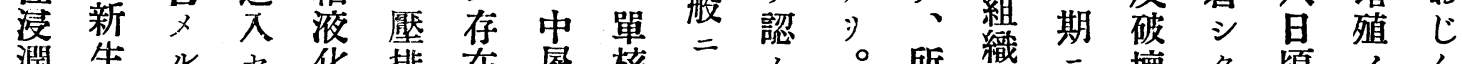

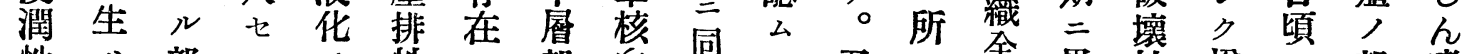

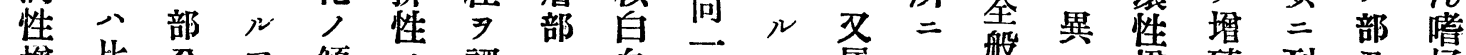

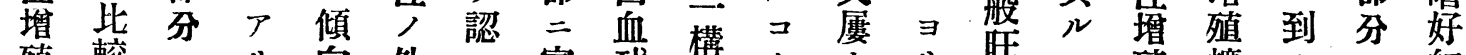

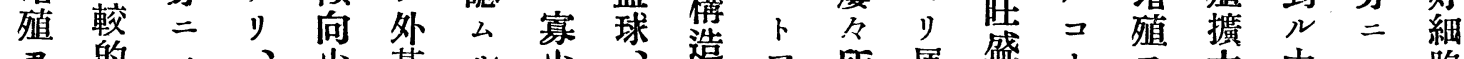
$\exists$ 的 、

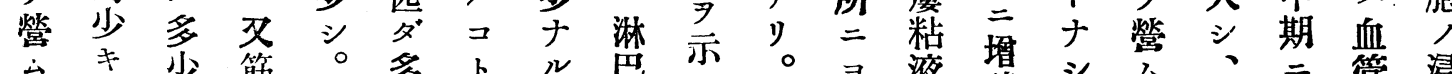

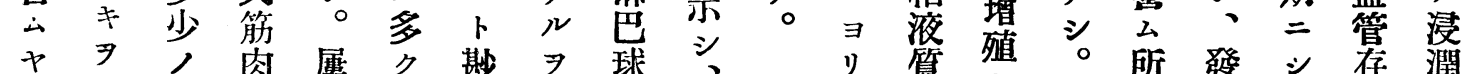

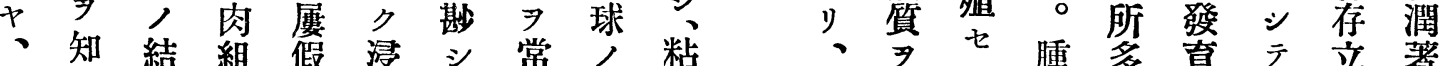

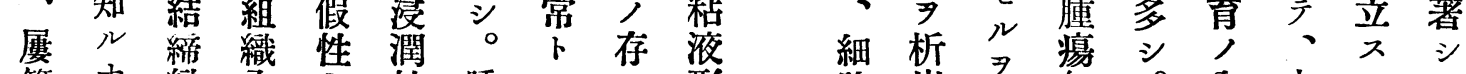
筋, 織内㐫性腫 ス

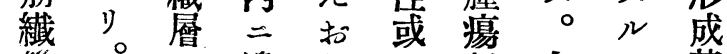
維 $○$ 邊じ采組 血 睡觀緣 h, 破織 管 卜 瘍コ沿好 性气概勿号 組卢七性ナ遗亦論長 織アテ細ル残相ナ長 内 残 モ 管多觀 筇存 、胞

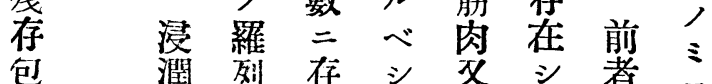
社性 $ᄌ$ 在。之主

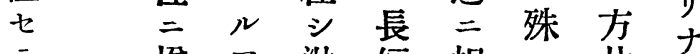

ラ 增 $>$ 淋短相三比

ル殖り。球維似邊較モ

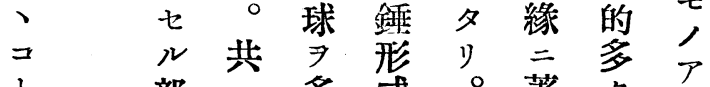

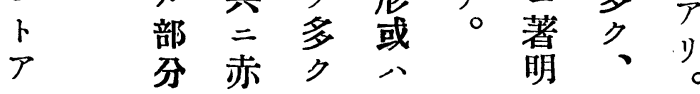

胞出 ${ }^{\exists}$ 細。全肉ルク 核 シ 認胞コ體眼モ、 人テ公、、寻的結 淋 加細 コ長二早二締 巴

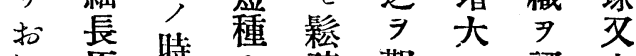
机原時々 踈 觀人認之 き形二ノ，壬頂么二 し質 处紡 部 バ墨 ル 準 1往丕鏠 分、 、令腐形三壓達如 ぴ長部細浸排シ $キ$ 存 々云胞潤性、コ 在

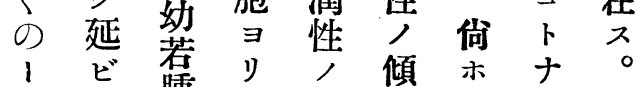

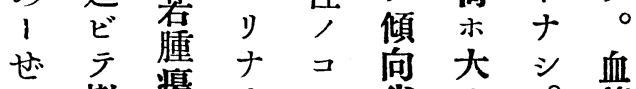
起臌細、、点佮著。管 起枝萢多殊 多著著 ル多二、明ク締 モハク、コ、緻ナ變織 


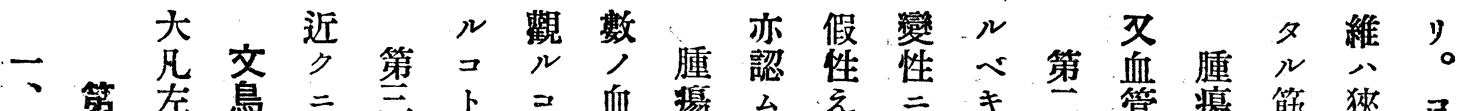

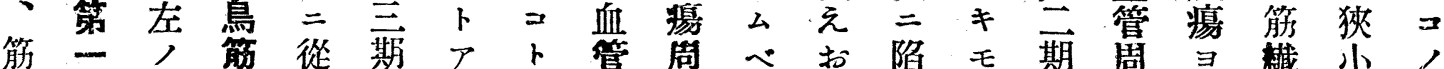



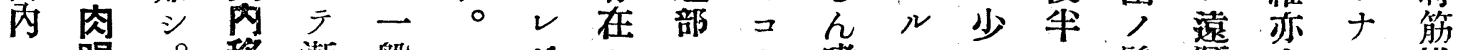



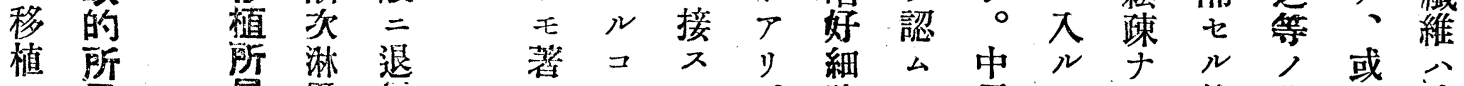
七見見巴行 シ

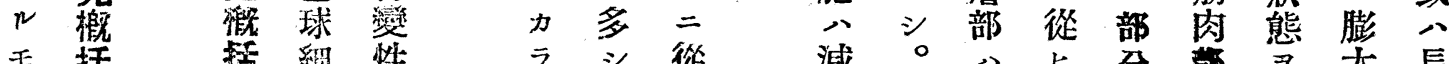

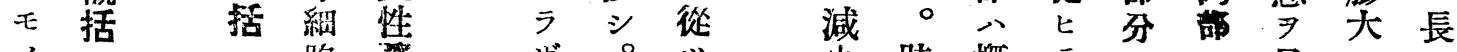

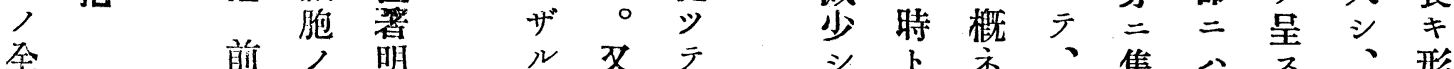

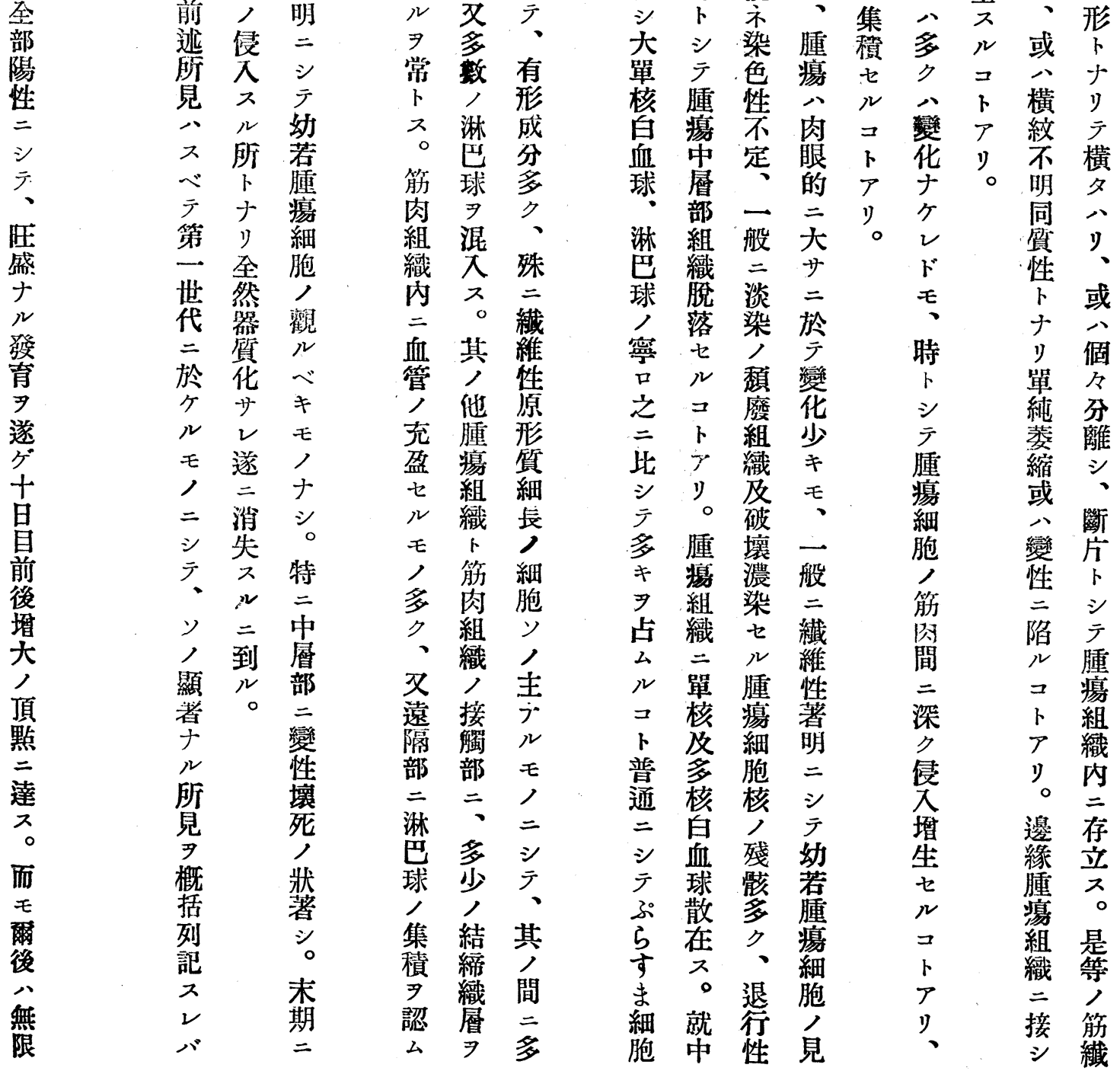




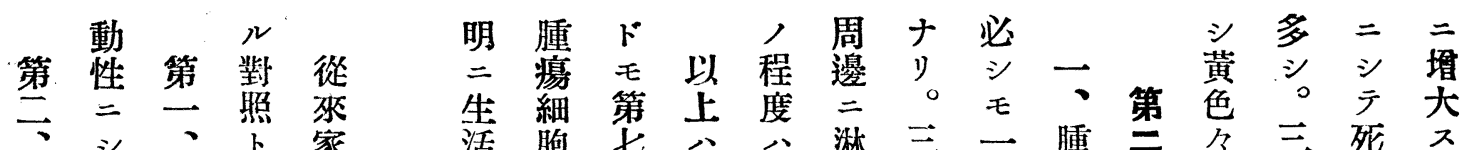
腫亏 腫 シ 活脽 胞芯

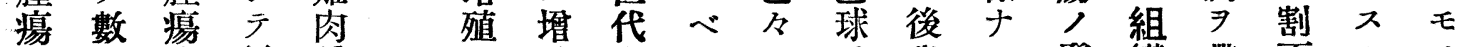

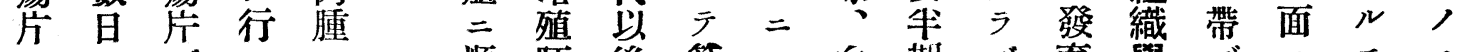

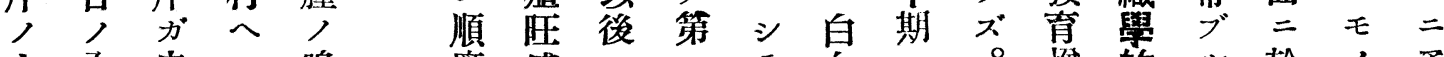
大內 皮ル鳴應盛

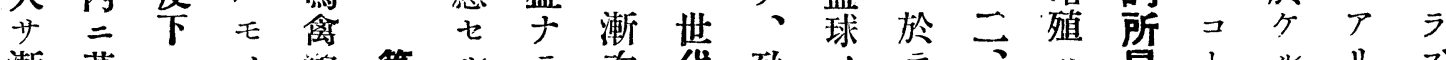
漸黄二八類第ルラ次代殆ノテ、”見トルリズ

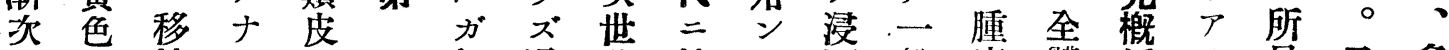

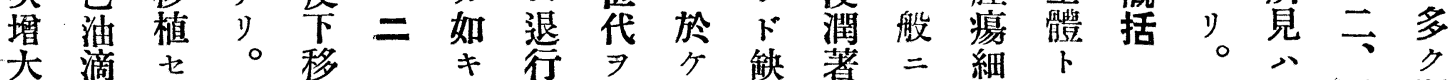

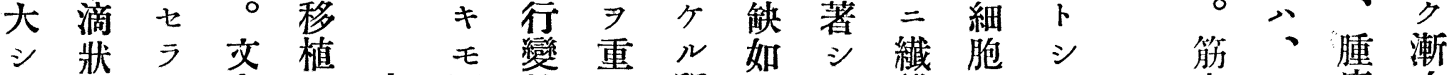

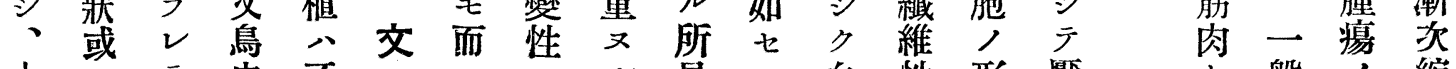

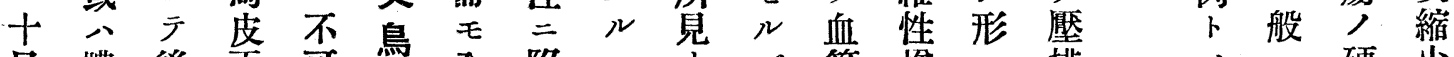

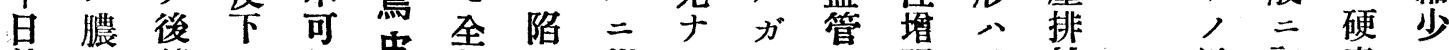
前疮著二能皮然り從 $v$ 如, 强、性境初度

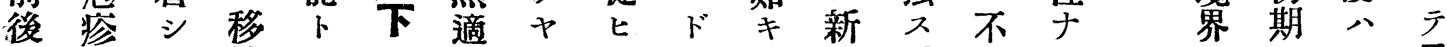

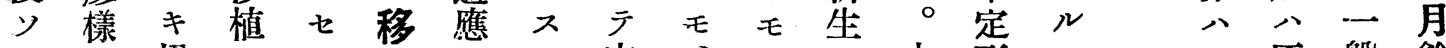

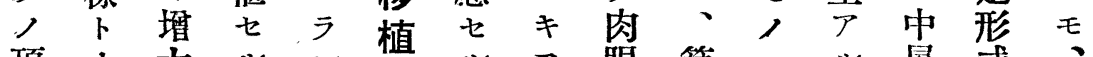

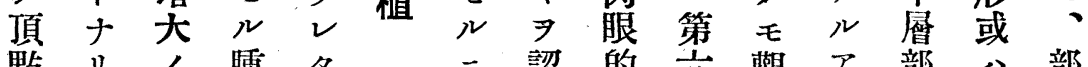
黣りノ腫タ 二 認的空觀ア部八部 三 數 徵瘍り 、公二世年 達週ナノノノ增代コド性短的 爾後、命著

後 吸 周二, 漸收圍 $\exists$ 文 次 消 二 リ鳥 縮 失著大皮 小 ス シ 略 下 シ $0 \neq$ 三 移

テ 變 㮔 植

一 化 三

月 兵 分

以年コタ

內 少卜ル



ズチノデア結シ令邊

家家度公り締名減殆方

雞䌖減殆。織腫紡於

棭、ド、細形、

於肉㙕之比胞二、

ケ腫殖較核 シ 浸

腫人同的㕣潤

リ 湯速樣弱變 特性

適細苞 湹 シ 少形類破

一匝 般 餘

般. 白 二

二白初 シ

鋔色期 テ

利 一消

ナ 全 稍 滅

り。體 䐻 歸

シ 中 $ᄌ$

テ頃 ○

實 以 而

貿 後 シ

性 軟 テ

二 化 時

富 ス

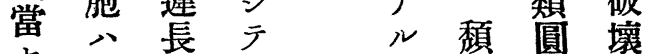

於落录六

於皮得多

縮华筋

小 二 肉

於丙

殆

$\begin{array}{ccc}\text { ト } & \text { 全 } & \text { 植 } \\ \text { 痕 } & \text { 可 } & \text { 於 } \\ \text { 跡 } & \text { 移 } & \text { ケ }\end{array}$

七文七著

$\exists$ 廢 形 性

王島 $ン$ 常, 幼

モ筋 ガキ ト 狀若 或

二肉如差

郘 異

又著細公

ラ 二、 7 之デ 八 排

ザ於組認等り 周性

ザテ織 吸策。邊ナ

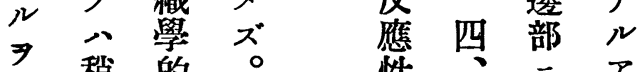

認稍的。 性紗 腫 著

メル文

ルコ鳥

モ

、多全

後 キ 身

二 營

到 末 養

り期 障

中害

層 骍 $尹$

粘 管起

液ナ シ

樣ル テ

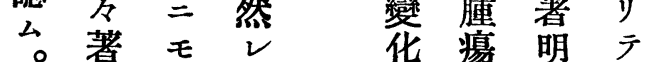

化 r 道 
細管粘 $卜=\exists$ 認實 $尹$ 於達二溢厂共 $尹$

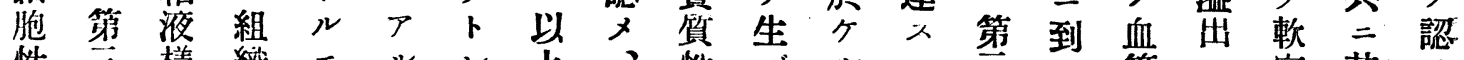

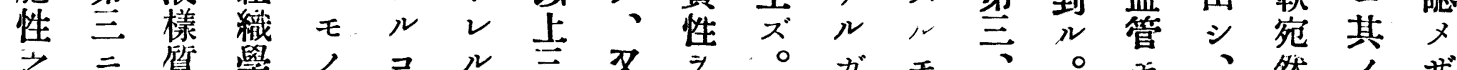

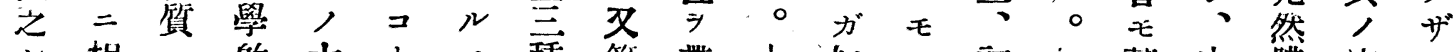

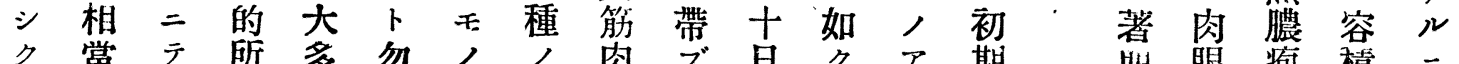

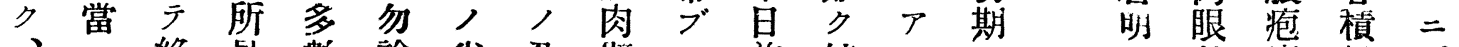

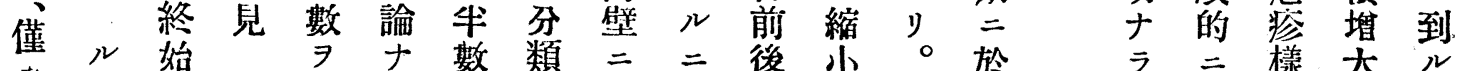

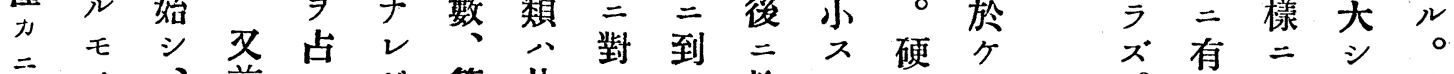

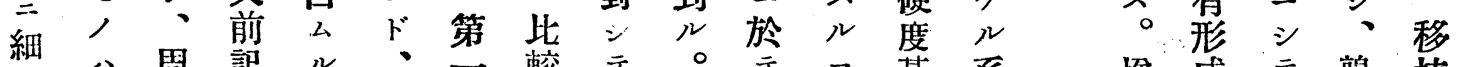

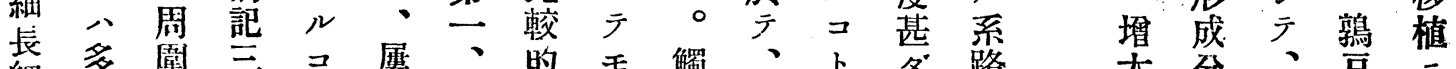

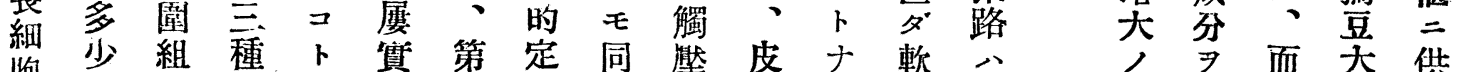

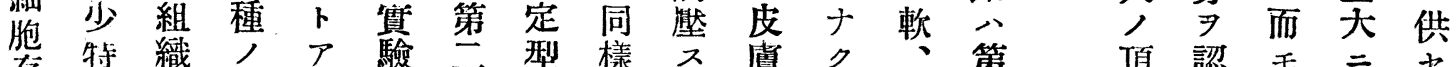
存特織

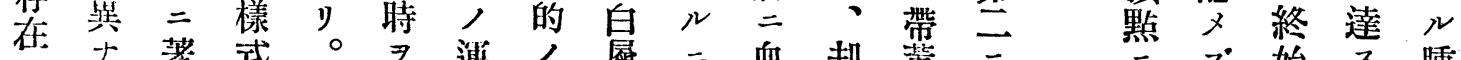
シ 極

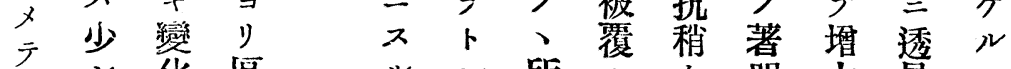

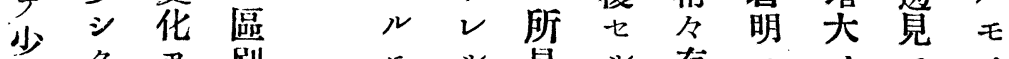
數詳及別二小見背存表傾入八

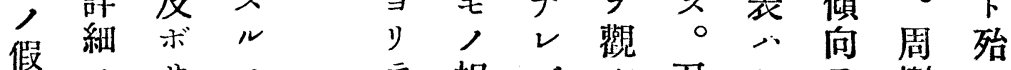

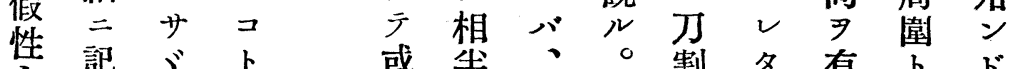

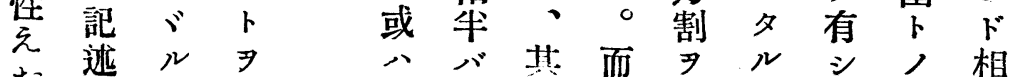

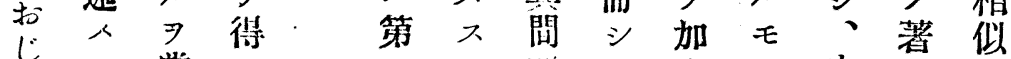
ん゙常べール諧テウノ皮シタ

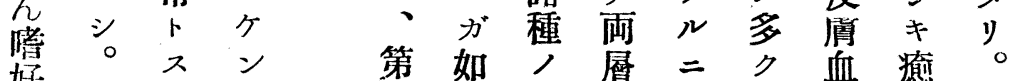

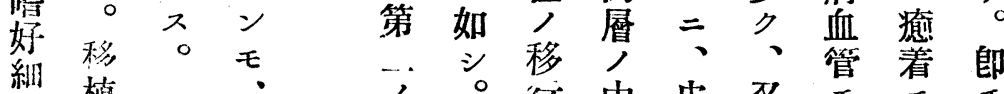

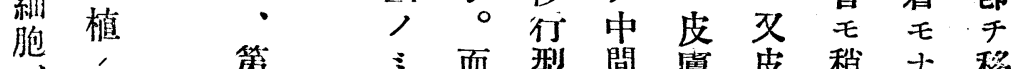

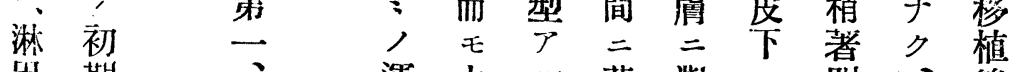
壵期運之心黄對三明、後 球第命等 $\ngtr$ 色 透占皮㫐

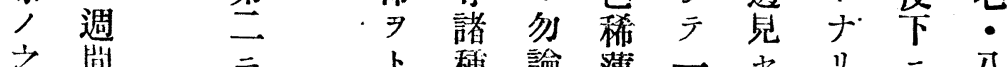
年種論溥二七り二八

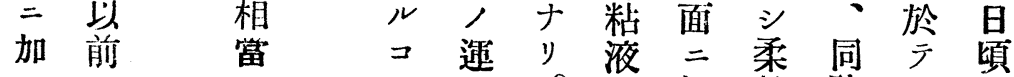
八八ス 卜 命。”板軟時可渚

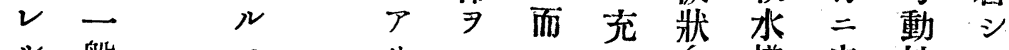

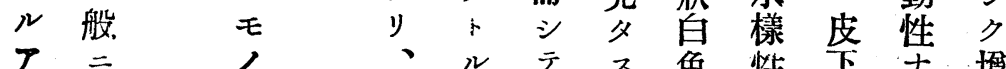

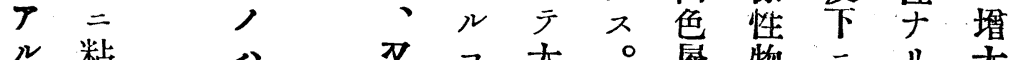

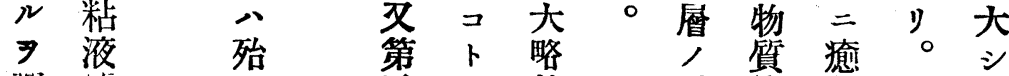

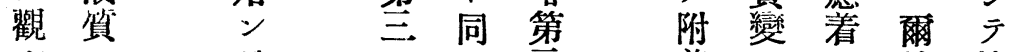

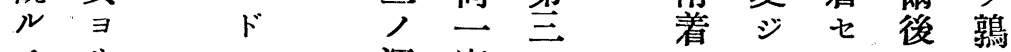

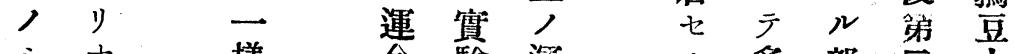

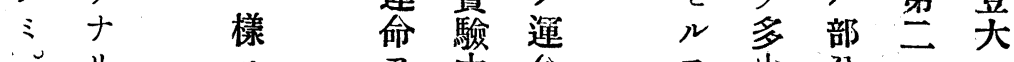
$=x^{\circ}$ 始 腫 達。皮ル㣎 七全下 $モ$ 組 少筑厂織

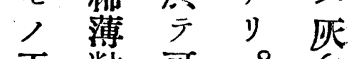
再粘可。白 七゙液動此色 縮 $\exists$ 性 小りナ特 八 入成》。皮白 $=儿$ 皮色 從 $\Rightarrow$ 虚多實 七 知二少背 、著緊細 漸。變張胞 次皮于シ 黄廦》、帶富 色及、黃 叉 , 筋刀白 色肉割色 モ 調 = 物 篔 癒 加貿少 加着フ シ 七透ナ $\bar{r}=$ 見 遂モ㓶之自 縮 $\exists \exists$ 指漸 小見》壓次 吸 ズ油ス軟 收。狀少化 者及物二 ス 少幦極光 


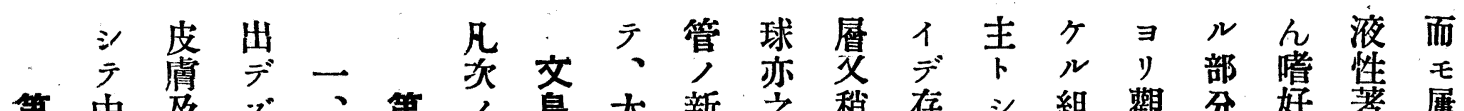

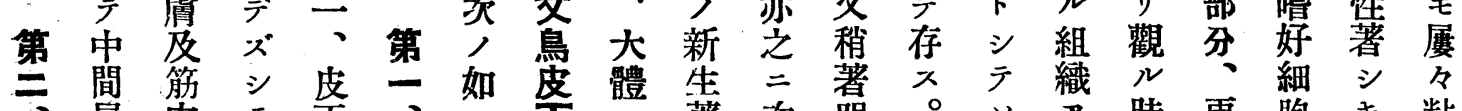

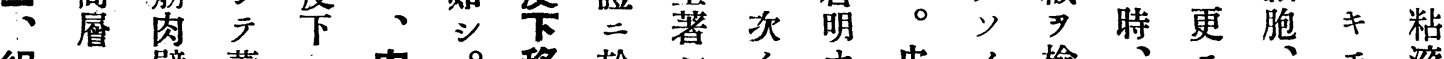

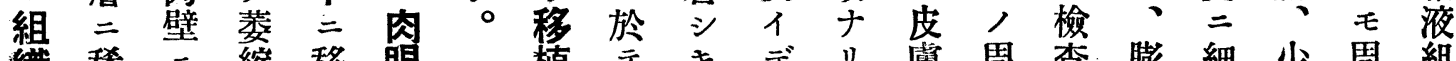
織 稀二縮 移眼植テキデリ佣周查膨細少周組

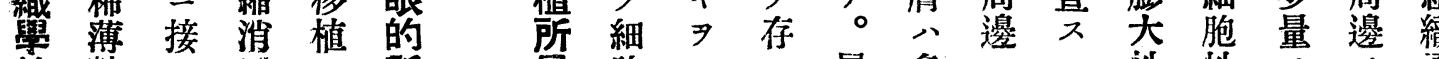
的粘 $シ$ 減七所兒胞認

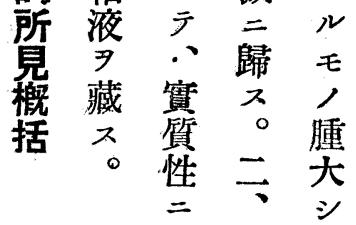
富 前 テ × 述 粘 鍾 液

板 大 腫

狀 七 樣

白 $ル$

殿毛呈

附、次

着 約 $€$

七 年

$\exists$ 例 $\nu$

觀 只

○移 無

コ 植 限

向 後

局早

所 前

皮後

䖉 大 $=$

血豆

管 㭆 5

著

琞熟約

几大手

$=$ 數

卜 達 例

多 シ 八

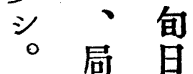

面 部 $尹$

概性公。乃少腫二三㙁淋皮軟

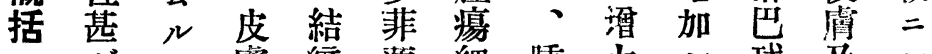

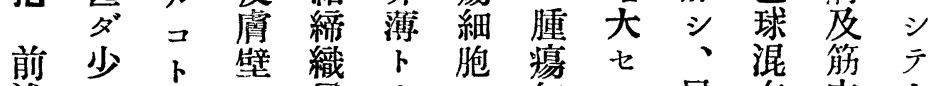

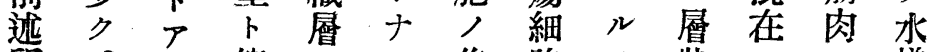
所、 、筋 $\exists$. 集胞 $\exists$ 狀 $シ 二$ 樣 見殊。因遗 $ル$ 積八認 $尹$ 、接稀 八

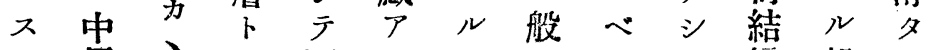
べ層之人深” テ部組移》。觀弱、箖織分二 第 八 組行筋筋劣少筋䠅、稍固 二 殆織 部 詹 側コ于側二血細定 世资像比 $=$ 上 代ド合較侵於多ド於着等性本



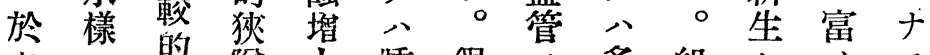
ケ二星隘大腫假, 多組七又ス ル軟早昷 ス湢性新少織ルル能

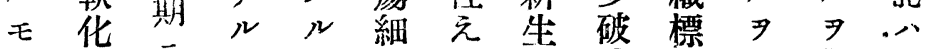
, 變 部モ胞お度壞本認觀ザ

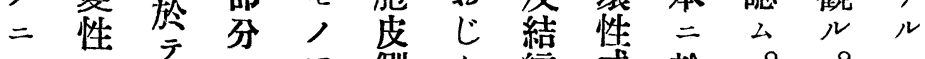
シ シテ三ア側ん締或於。○コ テ、モ腫り气暏織公示一即卜

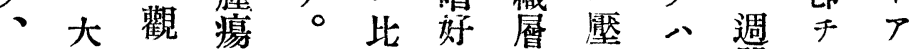
其部 $/$ 細假 $三$ 細, 排中間多》。 ; 分 ב胞性亏佨稍性層以少。 顯組卜多元一, 著下部後, 一

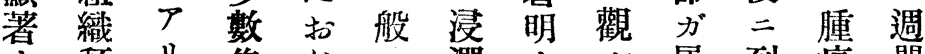

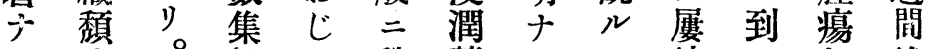
公廢。皘九稍著 所物以 $三$ 嗜多明 $\exists \neq$ 如㭙胞 見当上、好少二認・部入至 刃リ公又細、治分 $N$ 皮中 概ナ周屡胞血テ○モコ膚等 ゙ 括 $儿$ 邊力多管淋血ア卜庈量中

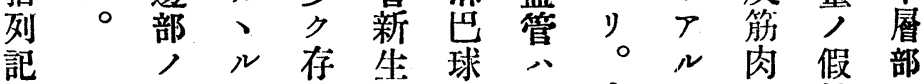
又所部在、充皮飞二性

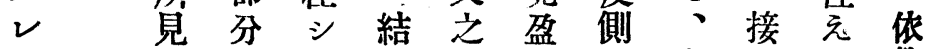
心 $\quad=$ 淋締 $=$ 感 。全 大三血巴織次、抖體夕心粘 


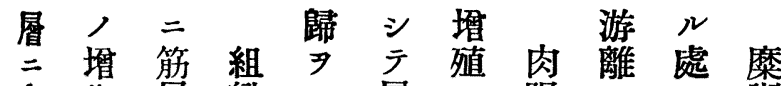

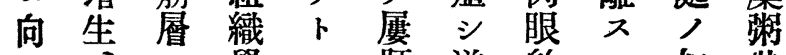

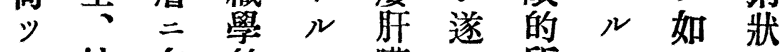

于結向的八藏三所モ

、締 $ッ$ 所腫等腹筧, 。細

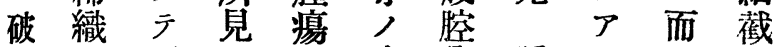

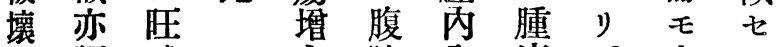
性認盛一天腔全湢。文的

或么二般人藏部片斯鳥腫

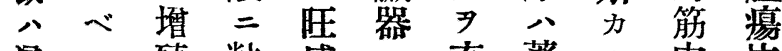

浸 殖粘盛二充著心苶告

润。七液广瘉夕明場胃专

性 即 $ル$ 性 $ル$ 着 $ス=$ 合八內

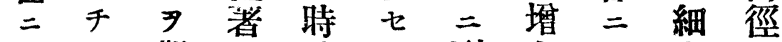

邽、觀 $シ$ 移 $\sim$ 到大八小元

盛筋ル、植ア师純二粍

三胃。シ 後り。コ交然 シ 套

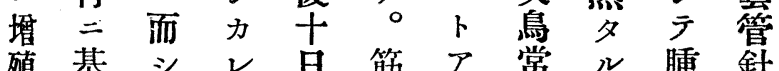

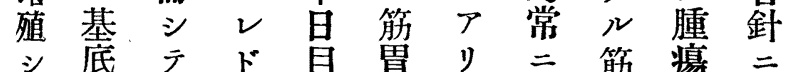

广 $\Rightarrow コ$ 前筋。死肉庍充

二才, 筋後肉而二胃 $尹$ 盈

部肉ナ三云到筋全 シ

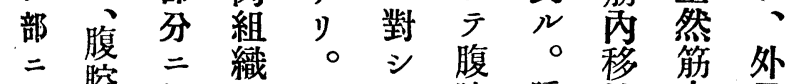

組管假 $=$ 腔腫植肏界

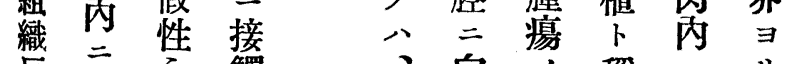

反.向元觸、向人程二

應・向和七割へ形

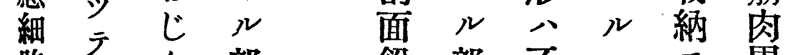

萢テん部銃 部不コス胃

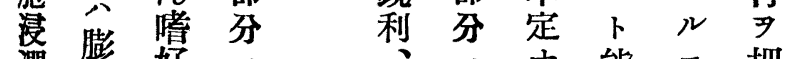

潤笑㚾公分能コ把

$\exists$ 性細腫細柔》公握.

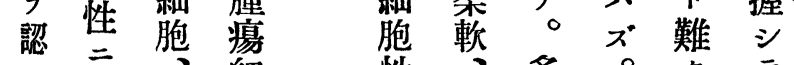

台著細性多。多方

者淋萢泉筋

巴豊富色筋霬肉

㙁球富 叉寒丙腹內

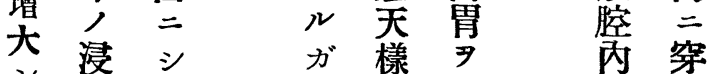

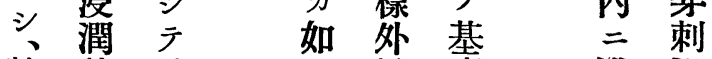

粘著破況䉀溢矤

液明壤

性 二 性

稍 学或

强テ、蓡

- 血 潤

筋 管 性
。

交呈

鳥等 膨

死 蝍

, 性 性

轉
植 較 速 胞 少 微

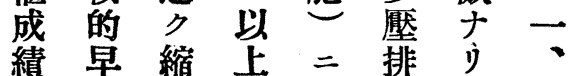

丕期 小富性。粘

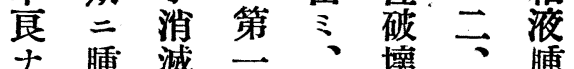

》癔二世腫性肉梾

組 歸 代 瘍 或 眼 二 織七皮細 八的終 二 ”卡胞浸所 始 第壞。移存潤見入 死 即 植 在 性 現天ノスナ 家所ルルリノ 、彩見モコ第 、 筋 決 粘 = 比占咅、 肉洨 海較?广y

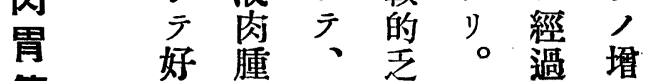

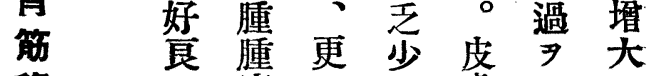

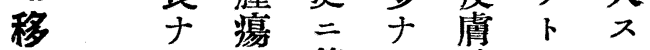
植細第》及吊皮为 環胞筋 $€$ ?

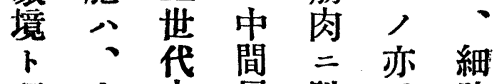
稱文皮層附管 入鳥下公着習 性 べ皮二粘七大甚 力卡移液次, 必 亏 二 植性 板 狀 尠

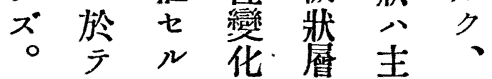

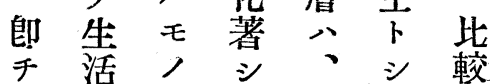
交入八刀淋云的 鳥为、細杷膨速 筋二粘 胞 球大 肉幾 液性 性二 二分腫稀白二消 於順樣 $于$ 血 ケ應多”。球テ、

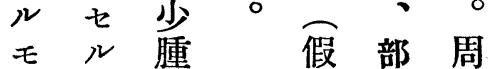
万ガ大性 分圍 如七元的 リキル櫋 變 モモ千核华 遙、, 九 力而 $>$ 嗜於較 $=モ \mu$ 好等的 


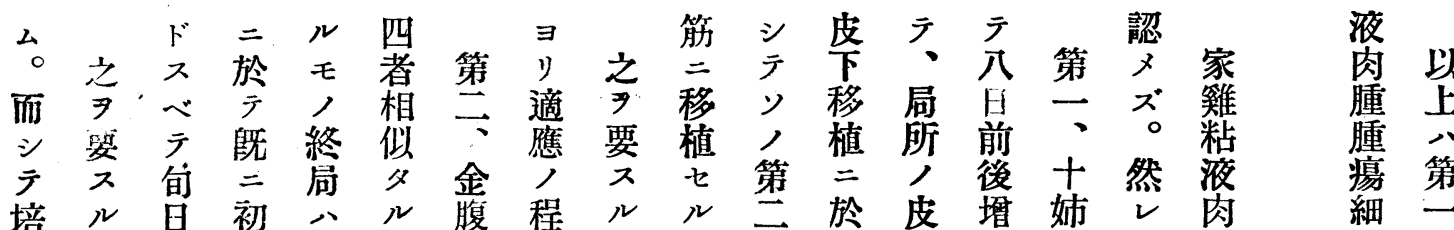

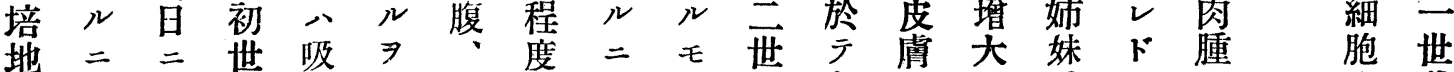

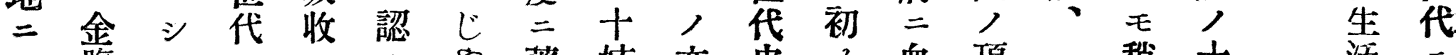

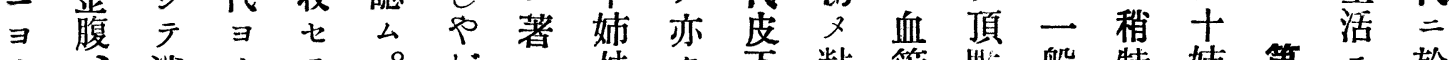

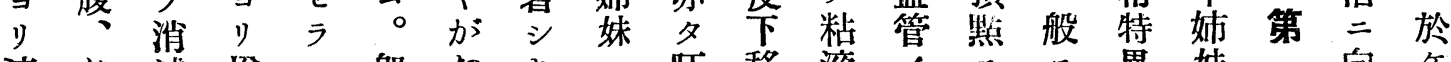

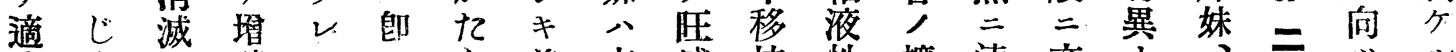
應や二殖テ

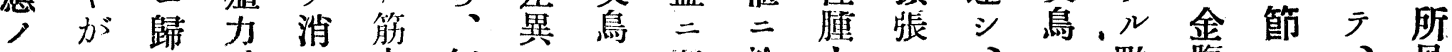

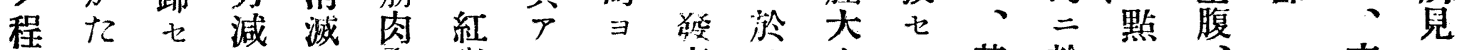

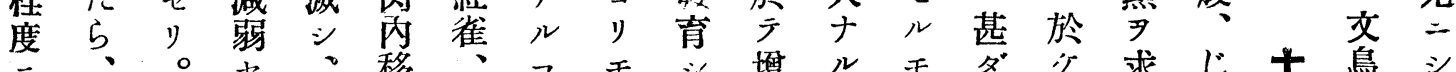

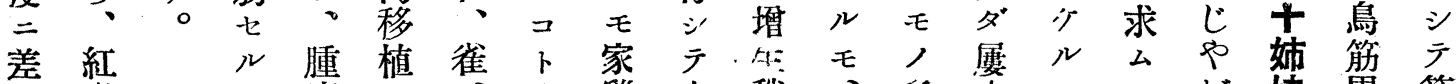

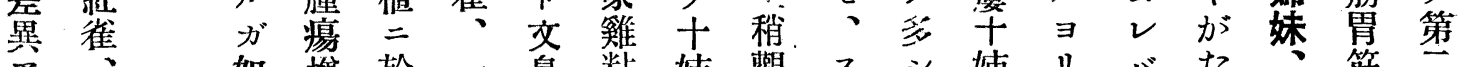
$\gamma$

雀

如 堆 於一鳥 粘 姉 觀 ス シ 姉り バた

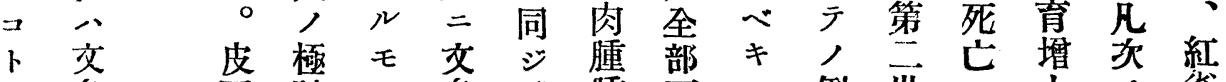

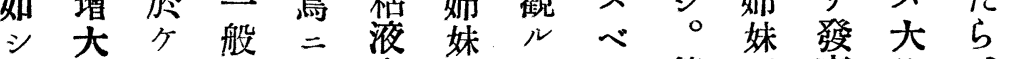

、鳥被, 鳥。腫死飞例世开 大

文. 移 被

鳥姉植植文於

十妹於公鳥ル

姉寻 死

姝 リ

同家

尉

栐 雞 次姝 發 粘 ガ 二 育

广粘 液 如 於覔

リ液腫キケ大

肉

腫卜ノ

ナ有り、梨

瘍

細

テザ壇 レ

胞多り大ル

增 增

殖大筋稍 如

不省学、

滴、ガ移二植

當如植定增

₹ 第 度 殖

ル 有芭塯自

認 有 世 殖 態

\section{痛}

胞りル於管二到旺 生。モ、漸妙盛

活 第局植 移り

增烈皮於䐈郎

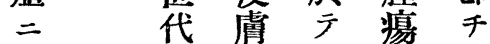

幾皮及筋

分 下 基 腫 增 肉

$\exists$ 移底湯大呙

リ植筋 增ノ移

多 八因大割 植

ク

適

㤫

セ

ガ

如

シ

而

モ

培
燃愿 極 合

㓌實十文 ケ

性 質 姉鳥

成 性 妹二モ

績 組死於

終織至到午

終增到ル 發

リ寻 E リ充

○生ノ比 迅

筋齐厂大速

畕而”。
人雀 U゙ト 側

p 三 胸

が テ 部

た 腹 筋

於ら犋肉

紅闪

移雀 露 移

植出植

雀ス シ

殖社 テ

態稍著

度適

、當㫜

交

$=$

於

ケ

r

著

シ

差
環成

境 績

研 得

公名

ค リ

。 䬣

天 
於上然

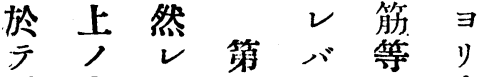

腫大ド—大 $三$ 夫雞

湯 サモ、凡移々粘

邊二時家左植檢液

緣達卜鴊, 七索肉

部入シ移如年腫

$=ル テ$ 植

腫事、見人成

陽 ナ稍筋

細》腫肉

胞 結 大 內

多局 严 移

少 消 テ 植

瀷先、二

殖六处於

七。界序

組

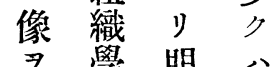

呈的力肉

不 $=$ 眼

モ 檢 觸 的

查 知

$\gamma$ 入 認

》) $ル$ 得 $x$

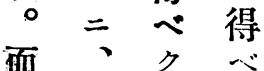

移、キ

テ 植 硬著

马後磨明

、全翌

二 然 $ナ \mu$

鳴 買少大

禽殖隆 节

類孛起澾

樢䛌認地

類モ㕕 ズ、

植 $r$ 速

阝

異 $>>=$

圣り。縮

時。少

黑

、テ䳝气

早初豆歸

期 期冭

小著所
八夕熟

氏斦家

等 $>$ 皮

, 少

夫而移

卜 シ 植

大 $=$ 数 於

㟟 見

当行公移榚

然水野鲳 。

然永离死

ド類安態

家 = 度

㜔鴨 $\exists$

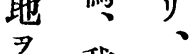

異 鷍

七鳥家

者及

著目甘

者鼠品

二鼠

實然䭆

$=\mu=$

於 筋 於

厂肉方

主出吸

寻皮收

卡像

㪙及关

麻筋島 適

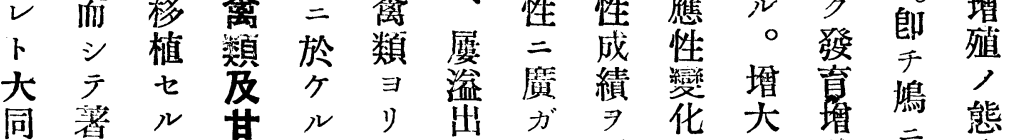

ヨ 植於 テ 著 堆一加 ”之分第 严大般再家 應 要 度云 世代花著禽略液 二ル代テ筋ナ明類迹肉 差二八稀肉 $\neq$ F二

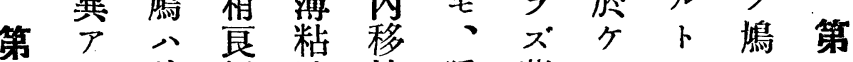

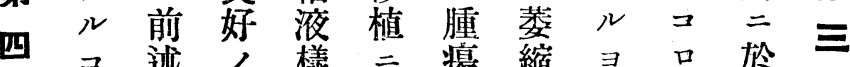

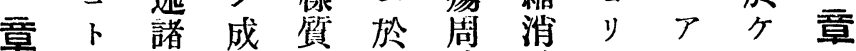
鳴種 績稍 天邊隇モルル

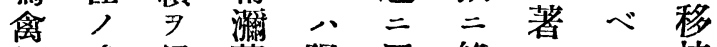
水類鳴得蔓陽 反終 シ シ 植 口下 $E$ E $レ$ 得稍, 殖於度 鼠同、テルべ著狀人令 家肝 ガキ明稍茈 臟 如 $モ$ 著少 移气度 粘 キ第り明弱植第 龿癒

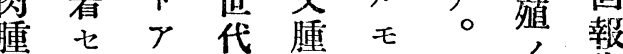
腫ルル移湯ノ筋態告

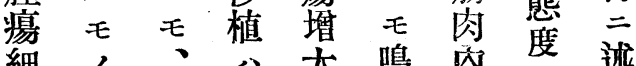

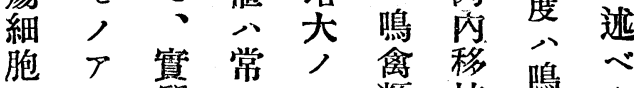
胞賽常人禽移鳴多 增。性不々頪植禽少 殖占成䲧於 $\exists$ 類所

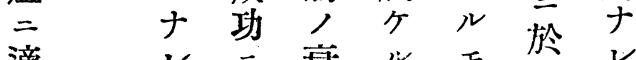

終第 分, 下

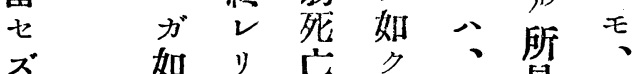
キ。著第見著 而直皮ルシ 点稍者 E 有卡ガカ世和 コ齐移如 $\bar{~}$ 代相其



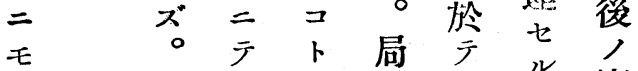

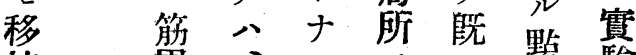

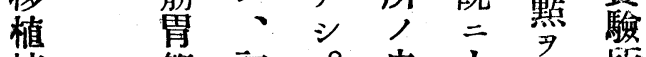
培镌初。皮大認哲

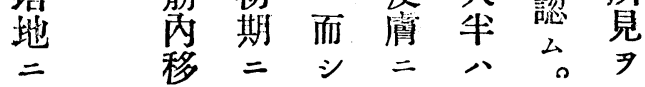


增ルケマシ 㕛鳥

殖、ルデテ・合二家 富、壬皮等於䌖 態垣新ナ尔 (16) テ 粘

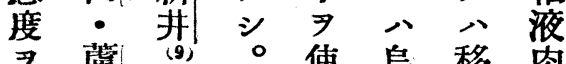
检原, 家用益植腫 索 (1) 腦彩七䌖不 7

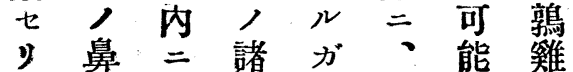

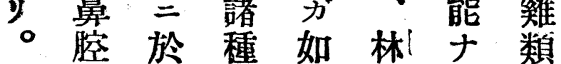
而內 ケ培 シ ${ }^{(20)}$, $=$ シ 二 テ於、三家”杉大植 其穴於䌖 (22) 七七

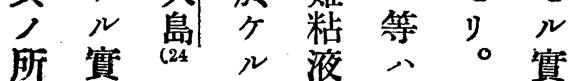
見驗 万移肉矮 其 驗 明少皮植腫雞公公 嘹。殖家移鵸力

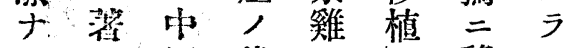

省相態二陵移

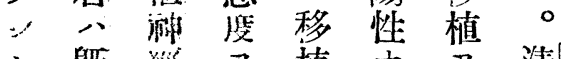

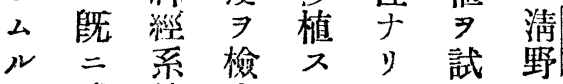

タ 成統 溹 ル ト 今

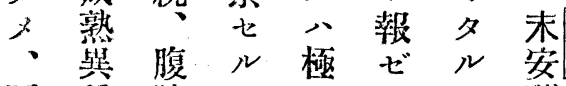

更䅨 腔 八メ リ 八 (21) 二族 、敖 加 三

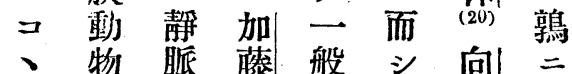

二物 脈 藤 船 三 向 三

䉆筋 雉, 行上

䌖肉冠皮一遮小移

類内等年ル諸杉植

中 $=$ 蚱 等陽

家华於㳩所命二等性

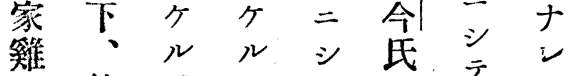

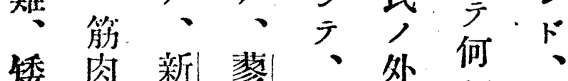



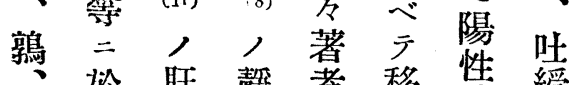

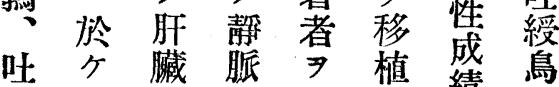

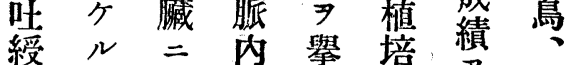

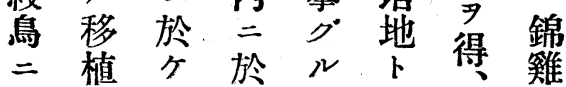

然壤 肉驗

リ之死内第例第皮陰到㾮

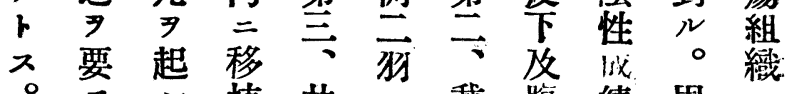
ス 、植甘二琶腹績周二

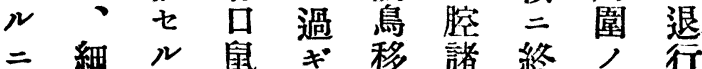
家胞モ移 ズ植蔵レ綵反變

第䌖浸人植。受り 應性

五粘潤、筋筋。性㭆

豆 萑 肉筋肉肉變至

肉名眼肉嘼化圔

腫著的内肙出

腫明二及移旰般 7

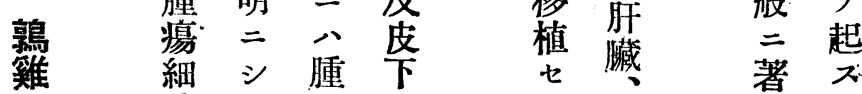

胞テ大

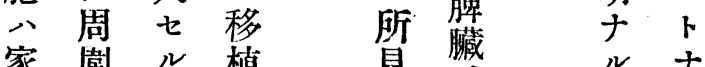

家 䔔 ル

皮睪毛り

琵淢所

鳥應尔見

及 强 $レ$ 八

艺烈ド、家

鼠ル組及

$=$ 織琵

沧常學鳥

$\bar{r}$ 的 $⺊$

生 ス二著

活 ○ 八

增屢腫 キ

殖出癔 差

ス血細 異

ル䆠胞

二 $尹$ 增 認

滴認殖

賞公像更

ラ $八$ 然

六

○ $\boldsymbol{E}$ ト

特りナ

二。ク稍

甘、特

口 速 異

鼠 組 ル

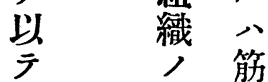

年望文而

、 全

腹移然

空植䍄腫

諸七如 湯

臟ル七全

器 ハ ル 體

$=$ ス $\pi^{\circ}=$

於 べ如 亘

ケテ キ リ

所明卡胞

見ナモ浸

全江閏

ク り著

家 サ

鴨 二

二 详

ケ で

ル

卜 速

同二

榬 消

シ

第 多

正 全

代 器

家 留

鴨 化

り 移 收

歸、植 消

但七公滅

實 。
著二細

ナ減芮吸 
到テンノ一

二世發、テ云組 共コり年、ル上。的述䌖

卜代充文其、織二

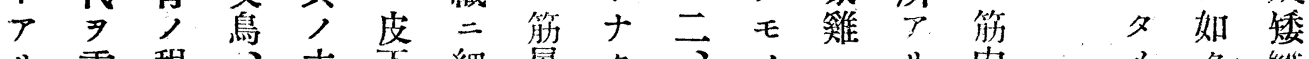

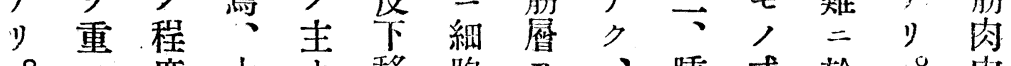

メ 㽞

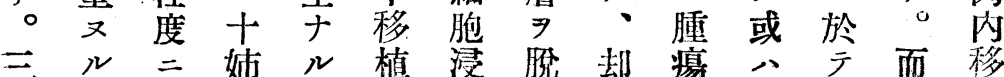

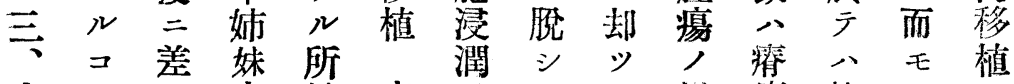

皮

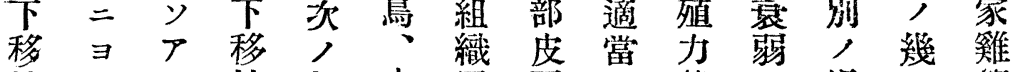

植り $、$ 植如十反市古䓕七場分筋

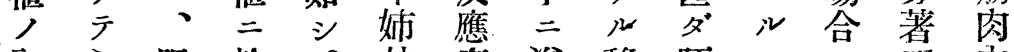

“初 亏゙ 限 於

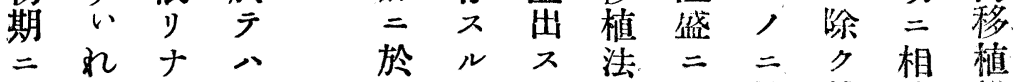

林存浴移旺モ尹明內

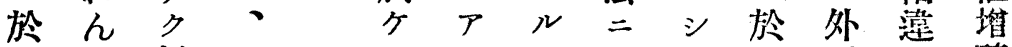

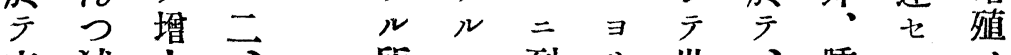

交減大

鳥少 シ 息、少テ代時癔 諸態

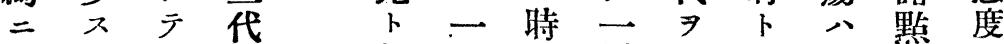

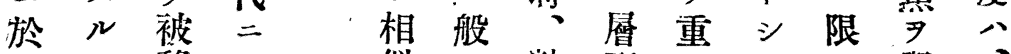

ケガ移 シ

如植 テ

ガ $キ$ 動 消

如 コ 物. 減

ク十家 三

粘夕死 ス

似二跕高 叉テ學

夕文液上ル或ナ古異

ル鳥性スコ程クン種

墨、著 ルト度增心゙族

ナ十明 $=$ 二 大 大

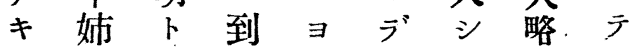

液、它次

性却スド

强ツルモ

灣 適 到 家

漫當り雞

性 ナテニ

稀 ル止於

薄 移公 天

粘植 ○

液法二苯

二妹ナルリ增テ次最

$\Gamma=N=$ 厂 大遂,

亏於。卜特七如移

ザケ而等别ル、シ 植

$\checkmark$ i $モ$ y $モ$ 家。能

ド 一。場, 雞率

モ, 般三合再屍

大り、變壃除 ビス

體弱性殖名縮 ル

集䔎 铞

用多 物

七 シ 學

モ而稚

ノ 柿

\# $\bar{~}$

五著 屬

侧者 ス

計來而

吾家 泊

士 雞

冽液 家

二肉肉

就腫腫

於少壤初处少 二

テ 科 家

、繼 䌖

於

ケ

移

植

, 增

筋 二,

肉從諸

內 事 培

,

第 度

ョ 增: 二

ノリ殖 自

如 二 力

キ 層 蕒 筋

於,死 初 シ 到

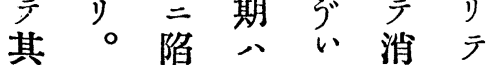

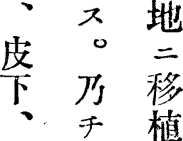

筋 其 シ

肉了

キ 交胃繁 、

$\Rightarrow$ 高 ダ 因

卜上陌 內

共粘水失止

ナス 盛卜

子液ん危台

盖

移名,

$\neq ル=$ 同

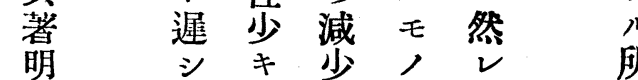

植 增

= $=$ 樣

モ ス $ノ ト$

四、ルモ

增 ガコン

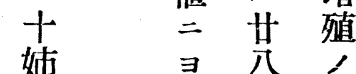

2 侧 所

實 及 見

$=$

於

驗 本 $尹$

所 年 检

一菑

家 䌖

บ y

附 矮

稍

器

o

墅

揭

○

兒

見公 学

見还以ル

ト 年後モ 
$(801)$

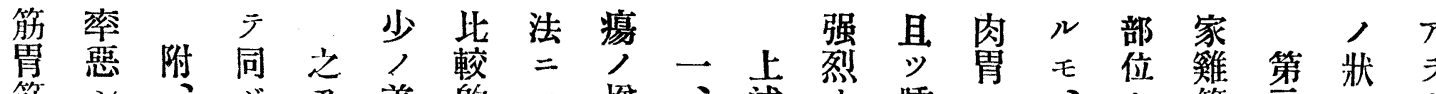
筋 シ ジ

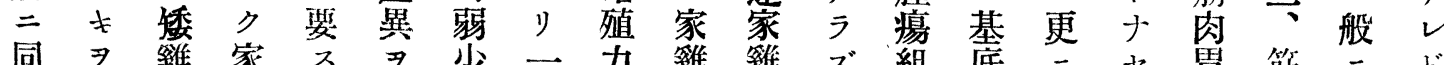
同 腫認雞家 盷 又家二

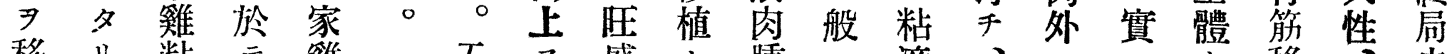

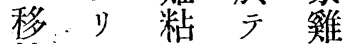

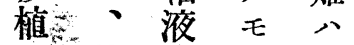
著肉培家 テ 学 腫 地 䌖 著 $\rightarrow$ 粘 明 年 矮 $\exists$ 液 ナ 齡 雞り肉 不皮厅腫 乑 明下適䭪 殖ナ二憵癔 擴儿移”細 大 モ 植程胞

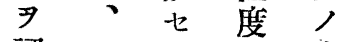
認y ”生 , 一 飞多活 夕趾, 少堵 。妇三美殖 特視榤䔬最

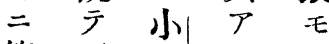
筋可杉皮等 鼻十, 码, 胃派”铅道 老告公篦 基矮宁べシ 后篧》。”。

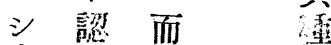
腹会等旅

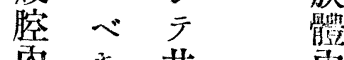

丙共共

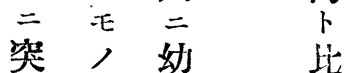

出三矮贸

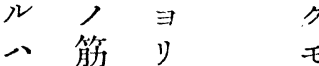

㱠笍老要

呙矮引

皮雉

跡卓移而

畉、植

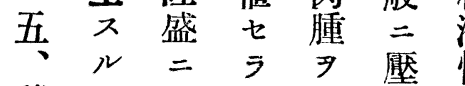

移

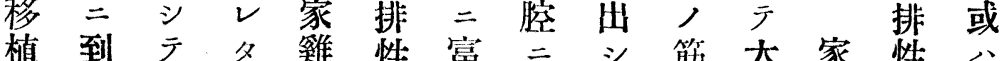

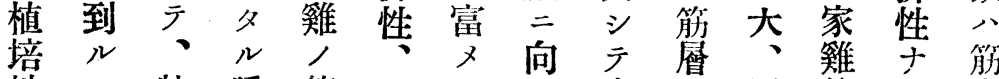

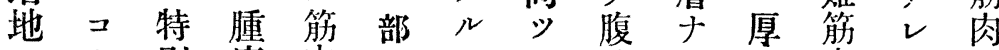

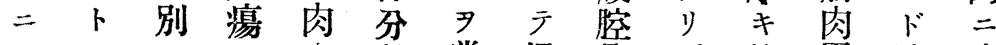

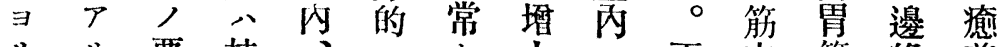

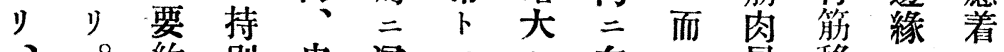

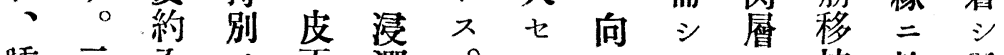

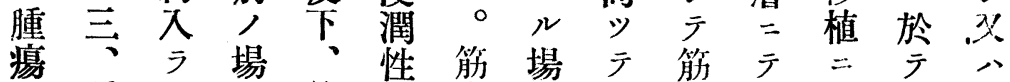

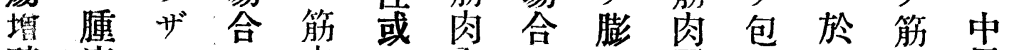

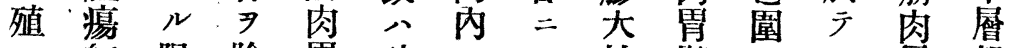
, 細限除胃破二八性壁飞毛府部

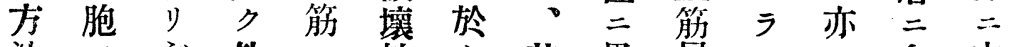

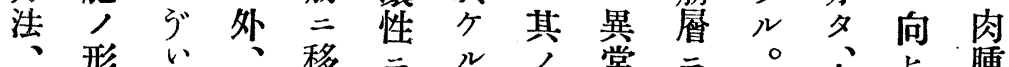

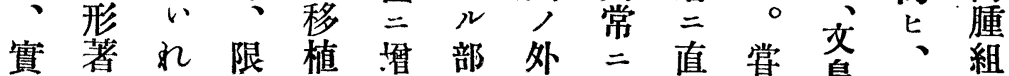



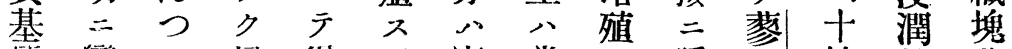

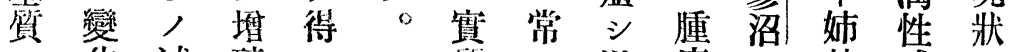

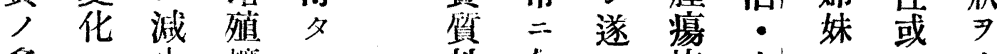

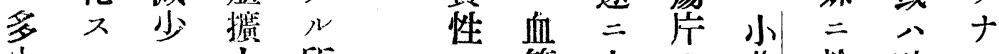
少 $\mu$ 不管小少此於破

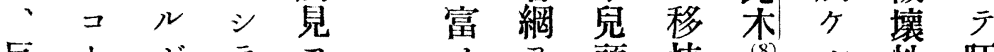

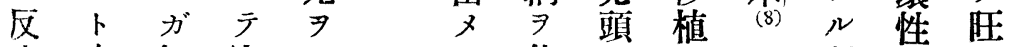

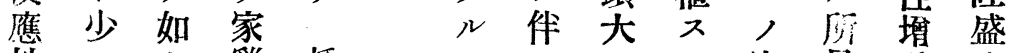

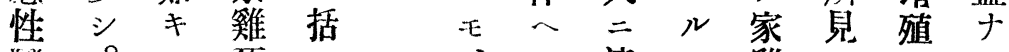

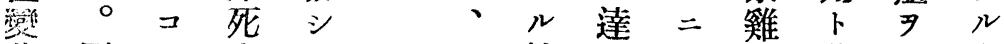

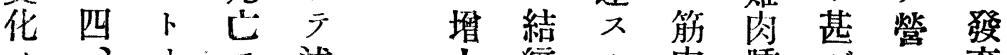

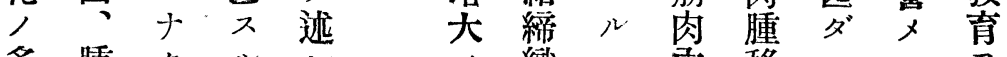

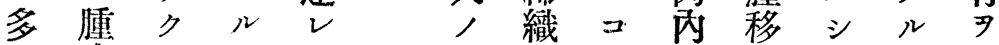

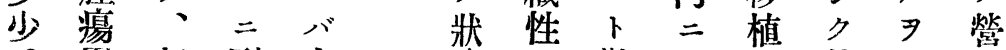

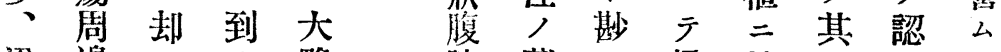

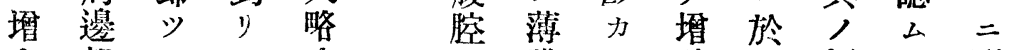

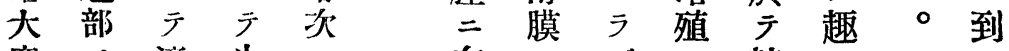

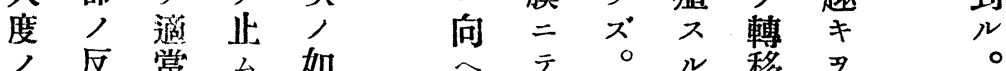

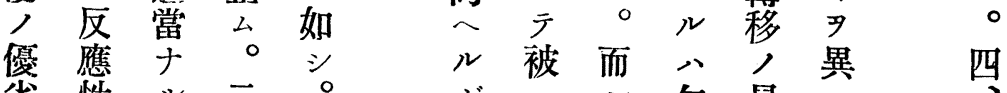

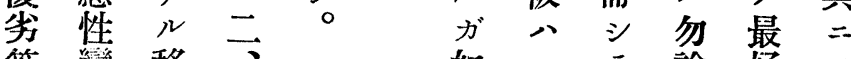
等, 篟移随

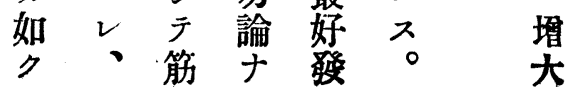


多 $\rightarrow$ 堆 八於 到テ實 ル 態

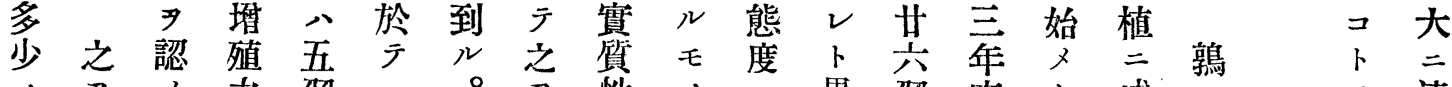

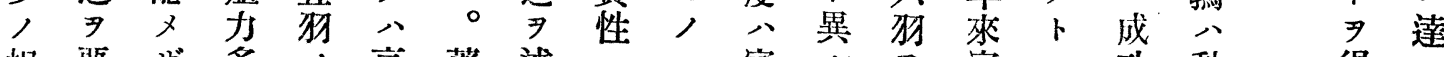

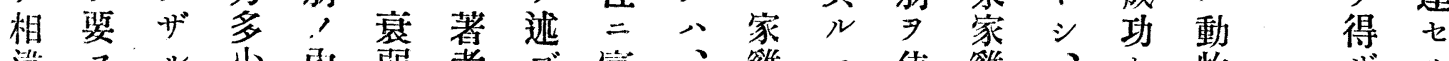

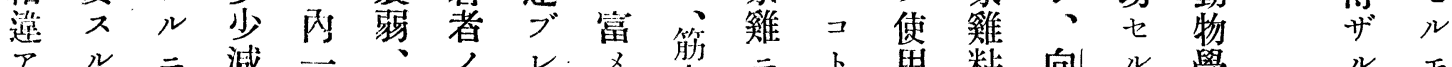

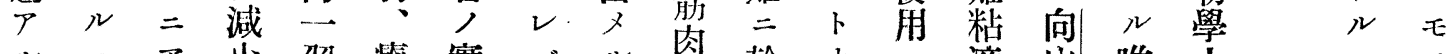

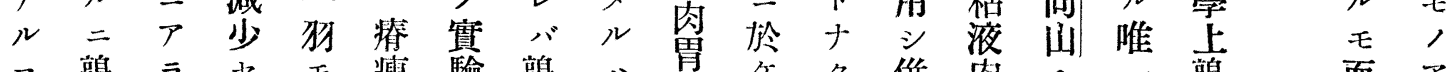

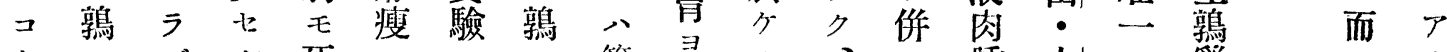
$卜=ス ゙ ル$ 死 シ

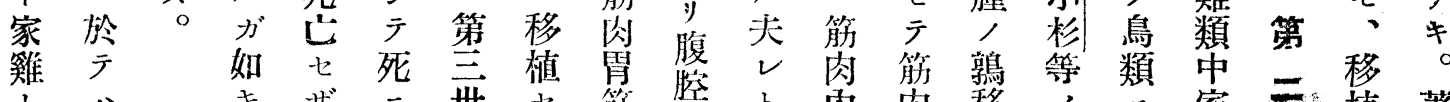

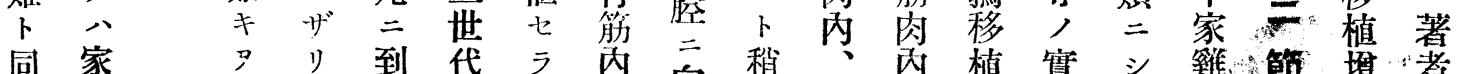

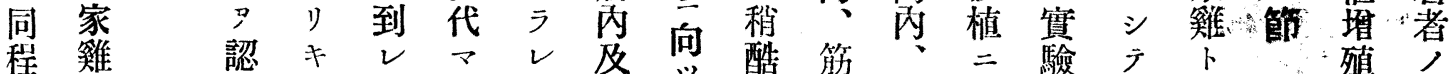

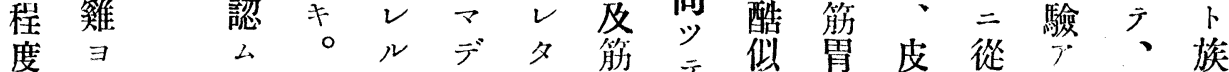

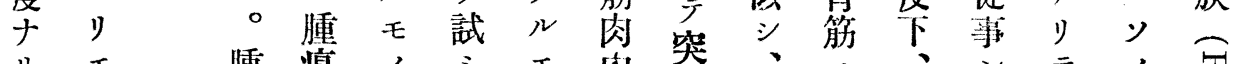

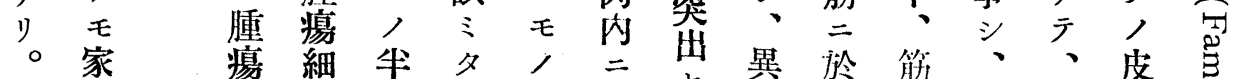

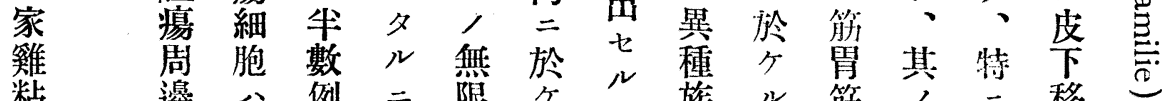
粘 邊 、 例二限年ル族ル筋; 液 遂 $=$ 過 $=$ 毛移 $E=$ 使清植 $尹$

肉應雞近ギ嘼モこ植, 於角野二異

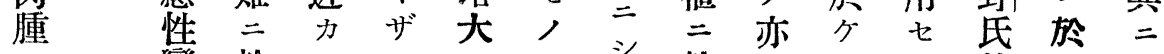
籆 於、

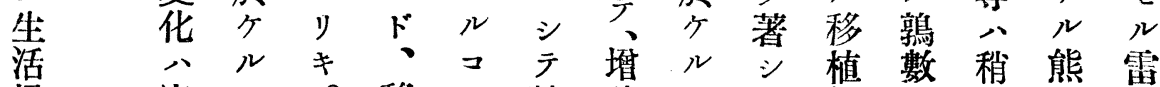


殖䌖り世植ナ液, , 差殖百細 $尹$ 科 二 $\quad$ モ 代方ク基此 $卜$ 異, $= \pm$ 檢 適同退 $\exists$ 法、質較八 $\rightarrow$ 態達ソ七屬 當 樣行重二一二的趣認度七, ル 七微性又遺定富辣キ又所ン所學。 ザ 弱戀ル漏度メ弱 $コ$ ズ見卜見者而

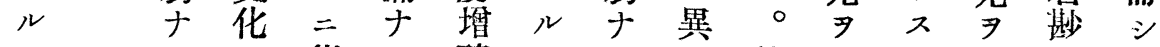
$\exists V=$ 從 $\neq$ 殖八ル二筋磪, 部力テ 認 ド陷七時七皮八不肉邓載亏從

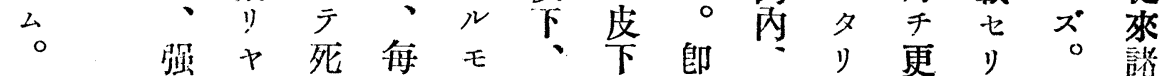

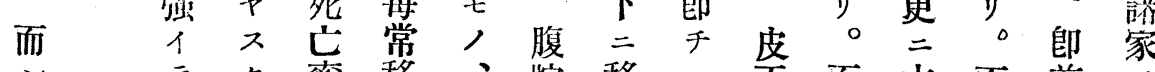

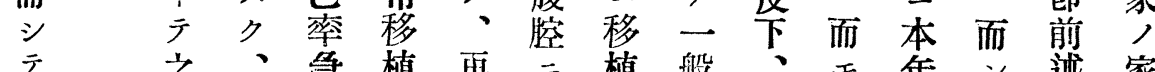

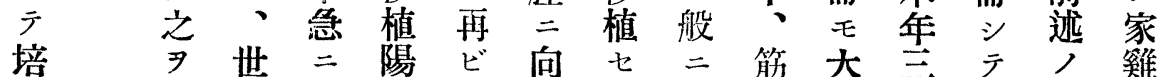
鶕 熊 䉜 度 全 於 體 ケ シ 實 テ 驗 家 例 雞 稀 自 少 身 二 於 テ 具 ル ツ 著 第

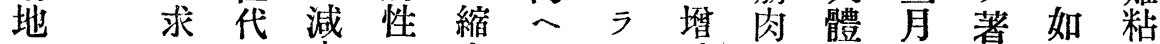

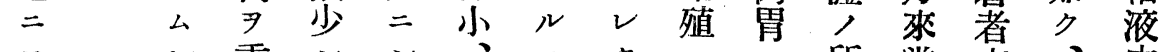

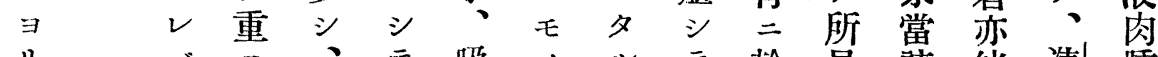
リ バヌ、テ吸, ルテ於見該他清腫 適多ル 第第收 ナナモ 最攵

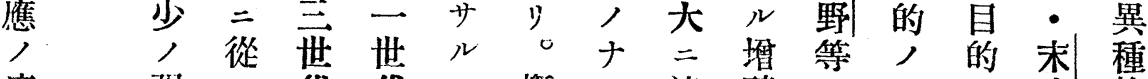



辛 差 移 墨 植 無 二 キ 消 ガ ギ 如 ザ シ ル 以 テ 直 千 論 結 ス 
レテ テ軟ノム異

ド必己モ化極。第 $尹$

モモ移 モ 織 後 ル

植 一紫二コ前無等 ズ

後樣的到占後限肉卙 二

期 見 テ 力拎增移于 二 二ズ○ 中 ラ 大 植之供 於 $c$ 一層ザ 八ス

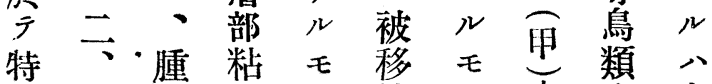

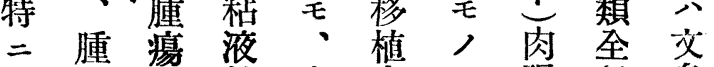
繊瘍 維細發著期眚乃的二

性胞育明再焒 ラ所亘十

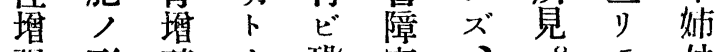

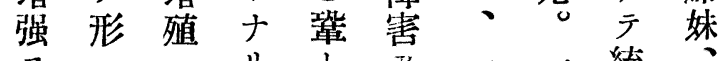
ス × 一 全 、 ガ般體黄 ル シ 度算的腹 如二ト色二テ二肉觀 キ長 シ色卜死達肉察

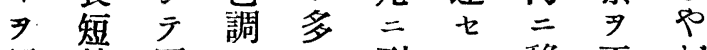

認紡 壓 $\exists$ シ 到ル 移下 が

么鋊排带。ル後植スた

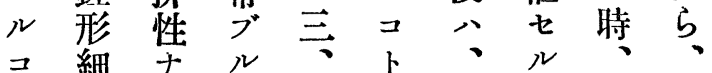

卜胞ル二割ア縮モ大紅

多当毛到面り少, 畧雀

○ナ部コ於二テ全人雀

三、、分

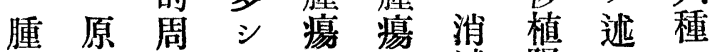

渲腫邊。八ノ隇陽

周湢二等一硬二性ルシ

邊細於肉般度歸二コテ

二胞 テ ト ニ



著 潤 境白般 $尹$ 、得 體 ル 性界或二常旺可人

反 $\neq$ 或 $八$ 初卜盛 シ 所

應差 八- 白期スナ自

性異破般色稍。ル

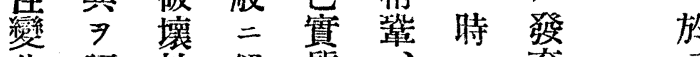

化 認 性 鍤 質

八メ广利性中腫習

此 $ハ$ ル 二㥧瘍 殖

較 00 ア
左

家

雞

粘

肉

腫

成

熟

同

種

亚

二括

異

種

族

動

物

皮

尔

筋

肉

的

及

算

筋

於

於

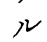

移

植

增

殖

態

度

所

見

7

總

括

著次

者要

キ 大

差凡

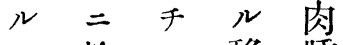

${ }^{7}$ 然二移腫叶。 觀ケ睎植ノ綬

タル言堛皮呵

リ $一$ 的殖卡 ノ結ノ移動 二 論 態 植 物 多 $尹$ 度不學 少下买可 上 增 ス 檢能同第 殖二索十シ ノト七比 像能》八鶉節 ヨ八。䠶 雞 呈 ス 而 二 類 シ ○ モ 清 二 夕 然第 野 屬 吐

モド世末心 , モ 代安 モ 綬

著 三 (21) 而

リ 者狗 實 モ

モ驗第少䌖

、侧 $\equiv=1$

而, 色七族

活代ル

- 二 - 所

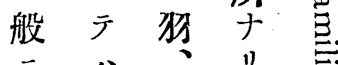

早、移完

何植而 $尹$

變 レ 佃 シ 黑

性モ數 テ 二

壤 著總著七

死明試者心

二十士亦哇

陷ル二夕綬

り垈 二 筋 鳥

漸殖 $三$ 肉科

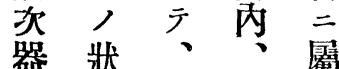

資 $尹$ 皮

化呈少例、而

レ ズ 數 筋 シ

消。甚胃 テ

減 唯 ダ筋家

二 筋 尠 二 䌖

蹛肉力於粘

七內直午液 
胞膨膨殆八肉又爾例 $三$ 又 以性大大連壁、後罗レコ同第ラ禽弱代以少

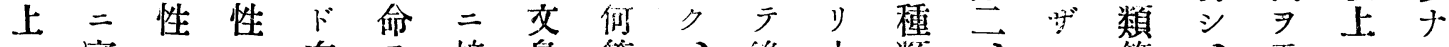

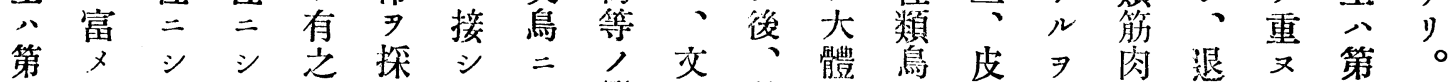

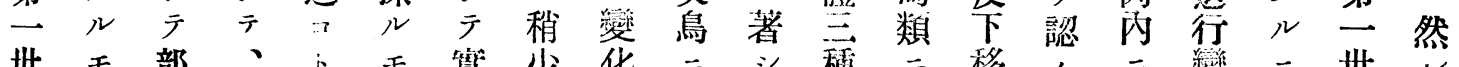

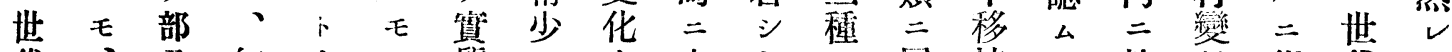
代、分細ナ人, 質クナ少キ三屬植。於性從代ド

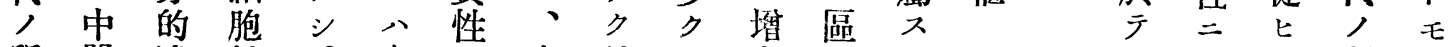
所間櫋性。十三十縮 シ 大 別

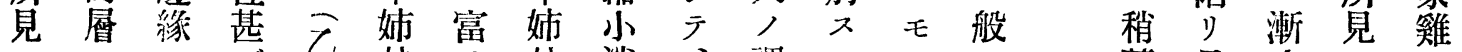

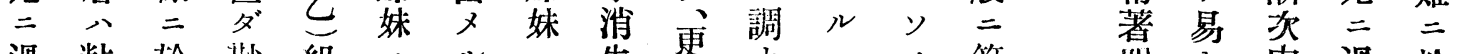

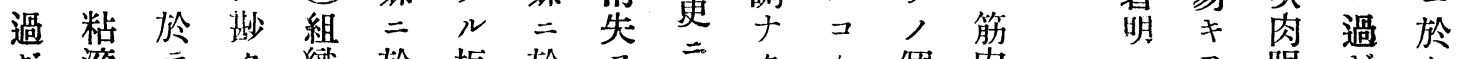
キ 液于ク，織於板於

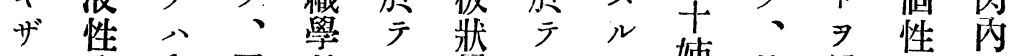
$\checkmark$ 變多周的, 八麼, 二 姉其得二 、化少園所砝了,

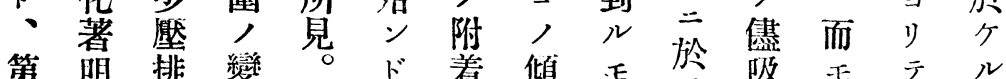
第明 排 戀。

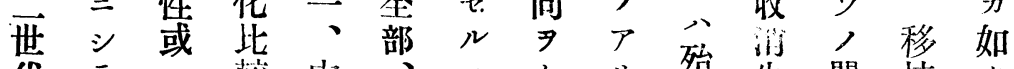

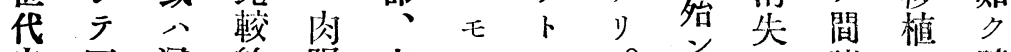
皮固浸的眼文ノル。光二䍀七然 定潤弱的鳥厂モ金有蹼種亏明

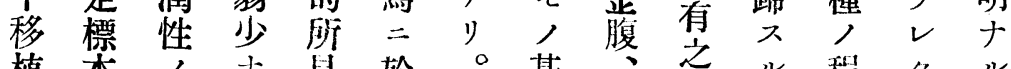
植本人少於。甚少已心程夕ル

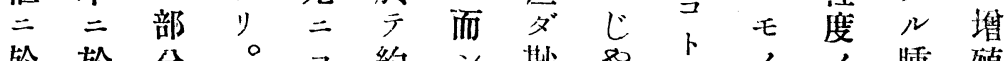
於於分。ヨ約

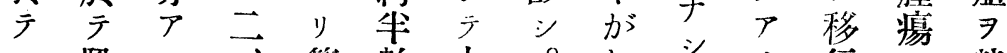

、脫ル・第數中高た高少行人營

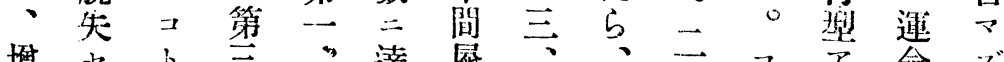

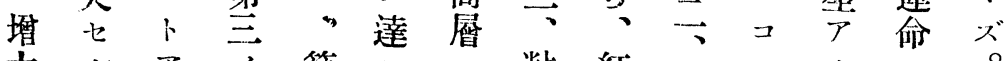

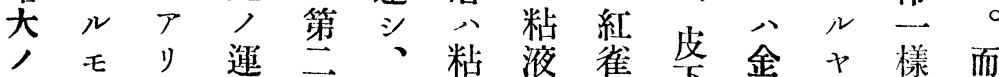

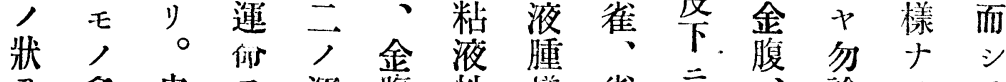

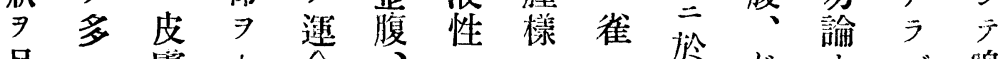

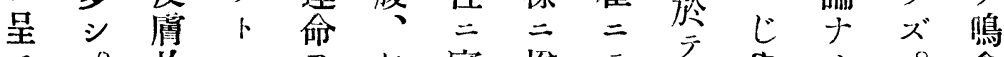

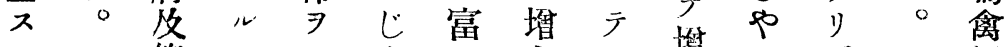
筋 E

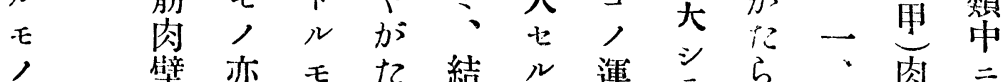
甚堡亦モ, た

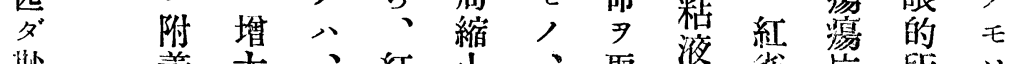

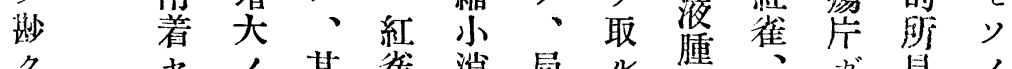



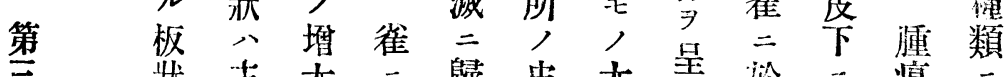

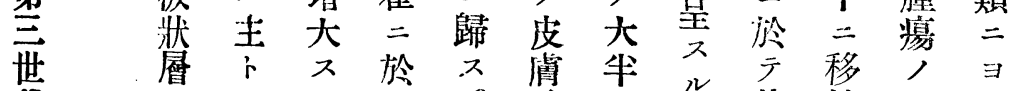
代、 $、$ 於 細テ〉八コ筋占毛基植運、

二 7 眼 ギ ケ 認的ザル

霓公二レ夫

殖 ○算 ド、 ス贠大、上 正被度第比

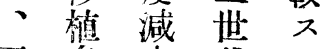
而鳥少代 ル

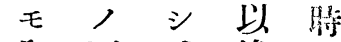
全死、後、 然岕 堆 諸 幾 順率 殖 種 分 應モノ鳥强 七非速類 ₹ ル代少二 二卜非 ヨ認 八其長引台 ア 二 七數 ラ䚄ル量コ 爻速召”的卜 ○北 多 家減尖少、多 於。組差 尔即學 兾 不的 $\exists 、=$ り リ家モ $モ$ 雞 腫 踓 滴粘序 當液細、 七肉胞一 モ細增 二 , 胞殖移 二八力植 
ス 變 然 度 績モ而筋テ カ

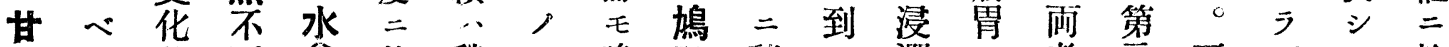

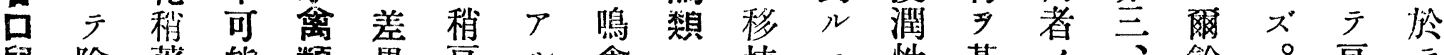
鼠陰著能類異 良ル禽植コ性基了! 餘。底テ

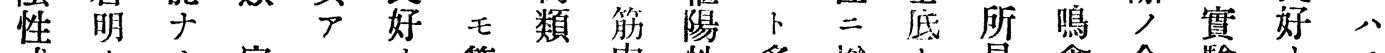
筋成ナり家ルナ第二肉性多塯卜見禽金驗大 肉績ル。鴊コリ主於內ナ多殖シ相類腹二ルべ

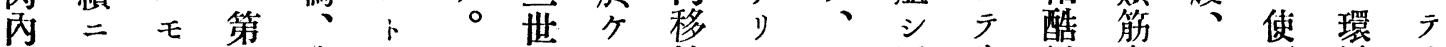
移終 刃一墔鳴要代ル植。一周腹似肉じ角境消

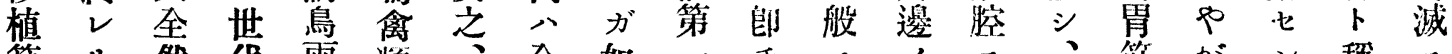
第り然代 両 類、全如

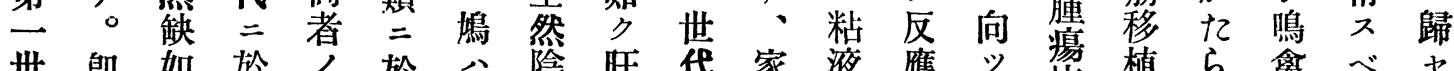

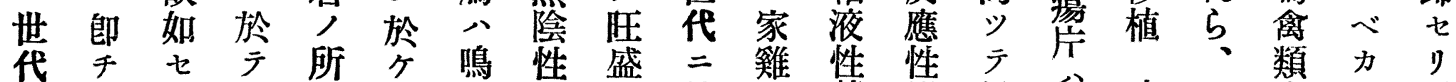

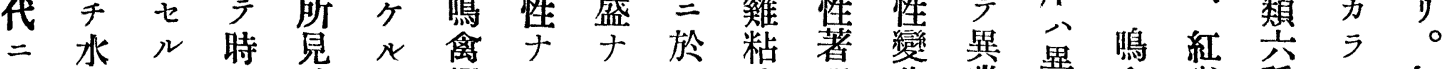

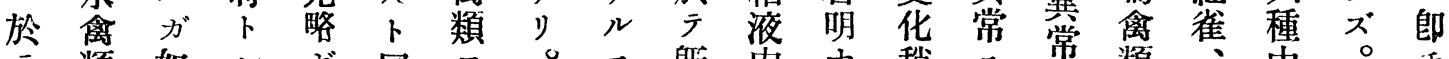

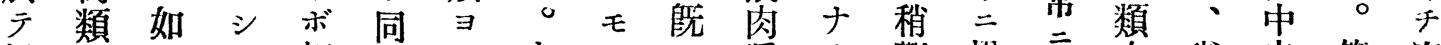

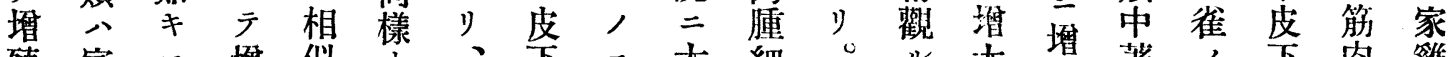

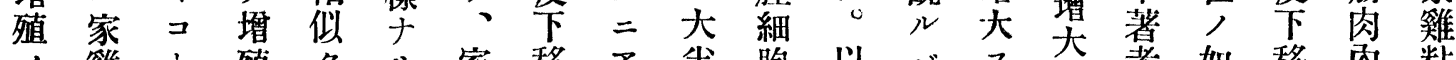

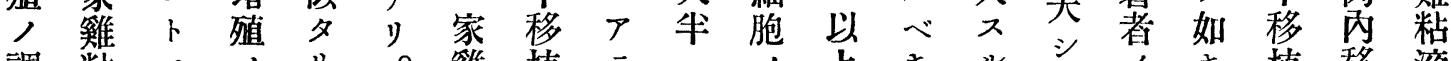
調粘モノり。雞植 ラ 八, 上 毫液厂像。粘二 ズ習增八部 $尹$ 被筋 八二 植肉 乇肉り $\exists$ 筋液於。㚐殖第分常被肉皮於三腫

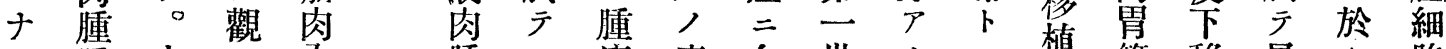

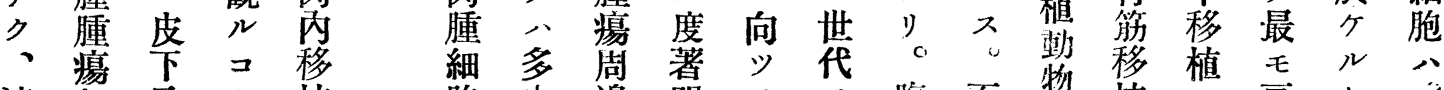

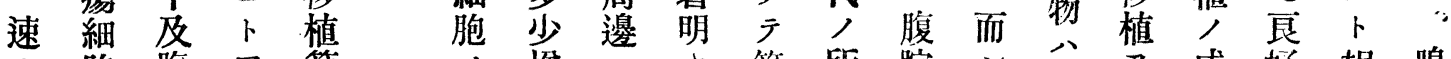
力胞腹 $>$ 第, 增人

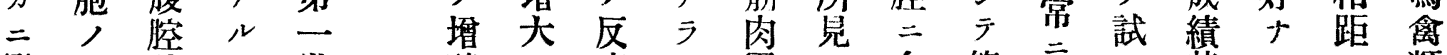

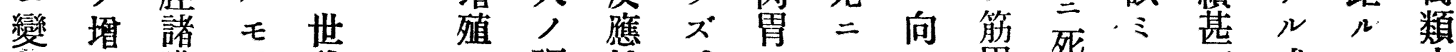


壤二器速二適 $刃$ 變 殘 稍テテテ笳到ル不綪卜下

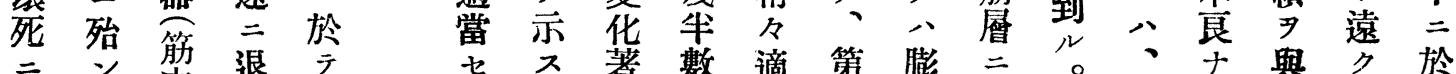
陷ド菑行 ス

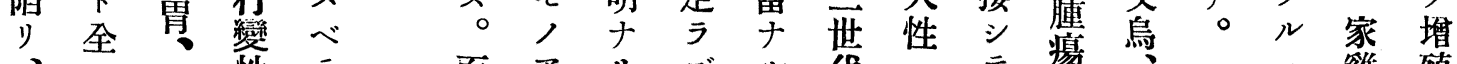

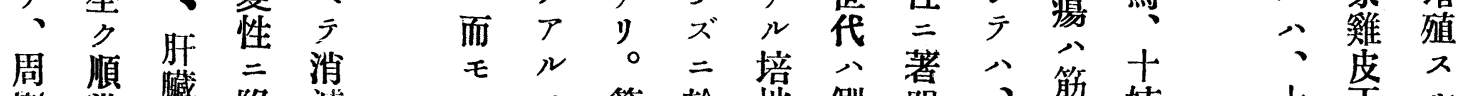
圍 當 㨫 陷 減

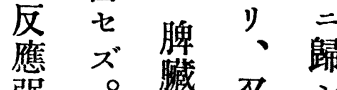
强。臟又 采 盛 罣 般 第

地 $x_{0}^{\circ}$ 於 牃

马 三周 世

常移邊 代

ス 植原移

ス 七 應 植

郎一性 全

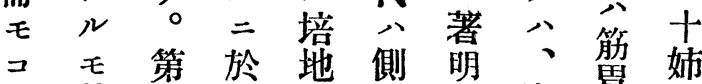

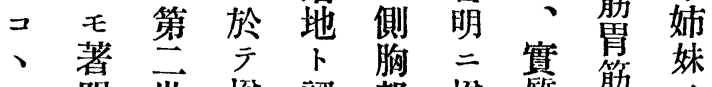



十华 ル

妹 植 幾

二 二 分 シ 於 適 テケ當 $\exists$ 筋 幾 々 以 膑 テ

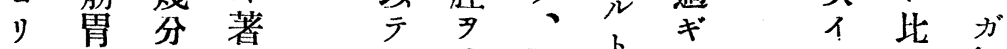
適筋增 明 七充壓同 ズ 應移大满排同。時。文べキ 程 植 


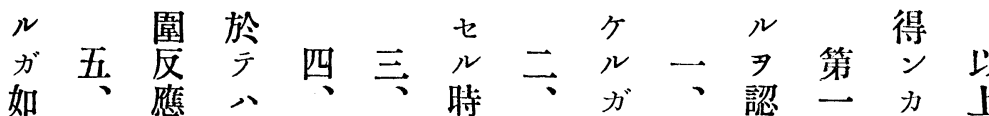

異 輕 屡 異 異萎 異如異台、述

殆種微侧種種縮種名種。家

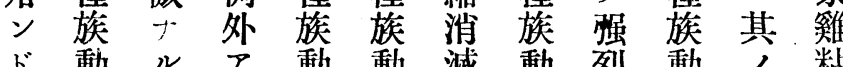

ド動 ル

限移卜厅移移儿中心移于肉

二植ア、植植 $ア 、 モ$ 植ル腫

移 $=$ り異 二 = 常種, 二點人

植於。種於於占族二於左異

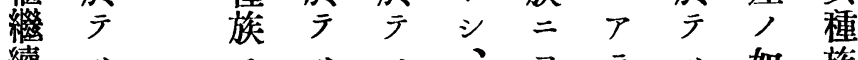

續 八

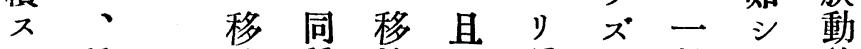

ル種植種植严腫。般。物

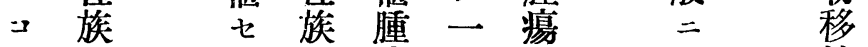

$卜=N=$ 瘍 般

能 寻特於分漖

八リ ケ退腫明

ズ移移ル行癔二

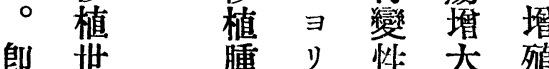

干代癔 モ

家 最

䌖高

粘兑

肉文

腫 デ

尹

全然

異 シ

種コ

族卜

動 7

物 ル

滴

應 而

順モ

化 同

七種

シ 族

ム 郎

家

工雞

$r=$

八於

現ケ
堆腫陷夕ル

大 惖

殿周ヤ被

耗邊 移子

ナノキ植ル

反 $\exists$ 動 $モ$

時 應 常 物 而

モ 性

刃變 万死 無

何强到

等 盛

增 ナ

大

学

翟常

呈 ᄌ

七。

ザ 然

ル

時

E

共

堚

周 $=$
到 二

ガ大

如

$\neq ル$

ב

尠

尠

ラ

ス。

定

度

二

達
腫

燷

殖

發监態

微度

弱

$=$

テ

同

種

䬣

夕

r

t

t $\quad=$

昆於

盛

ル

霬

殖

再

管

么

モ

$=$

踓

踓

モ

同

種

族

$=$

於

於

熊

態

ト

間

間

量

的

差

異

存

在
見 類 ス
$⺊$ 鶕 甘

酷 植 ガ 雞 口

似 二 如類 鼠

於 キ

ケ コ家家

ル雞 雞

家卜之粘粘

䌖

粘

液

結相ナ液液

似 シ 肉肉

タ 腫 腫

り㕛实腫

腫的變家演

同

種

整

二

種

族

動

物

移

植

增

殖

家態

䌖度

幕

基

ト

シ

テ

庩

ク

八次

數如

結

論

ス

ル

ב
雞 壞二胞

類死移,

中 二 植 發

鵫陷入充

八ルル增

鳴 $コ$ 二殖

禽卜、

類 掘 一 全

二 ク般 然

於、 二 適

ケ周旺當

圍盛

所反

見 應 發

二 少 育

相 湎

似 殖

夕移 三

り。植 テ

又 地世

䳏 = 代

雞 $\exists \exists$

類 ル 重

中 買 邓

吐殖 ル

綬 ノ二

鳥態從

八度 匕

水、宁

禽周

類韋必

於應 九

ケ等 つ

$ル$ 鳴 減

所禽少 
E

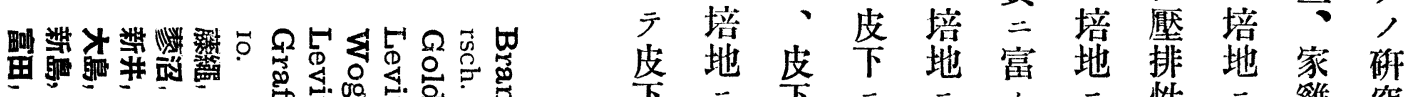

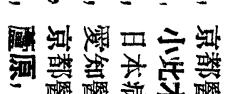

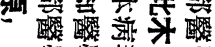

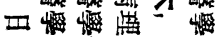

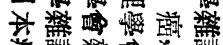

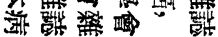

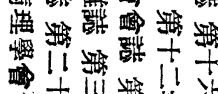

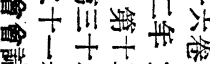

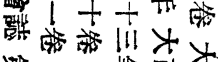

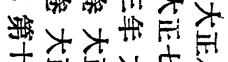

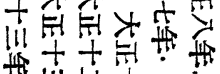
init

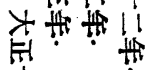
of

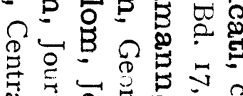
일

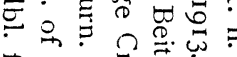

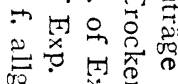

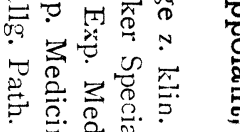

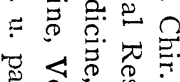

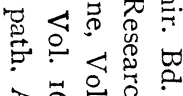
>

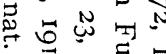

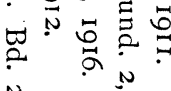
N

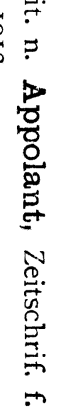
it

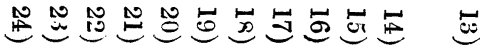

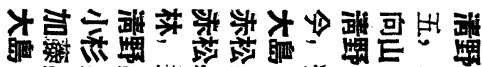

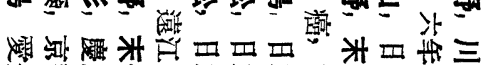



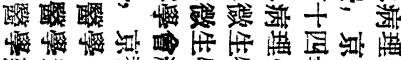

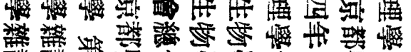

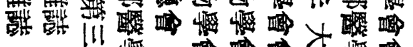

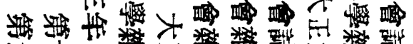

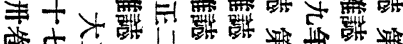

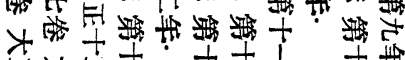

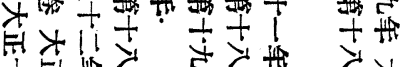

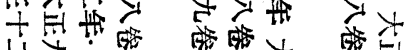

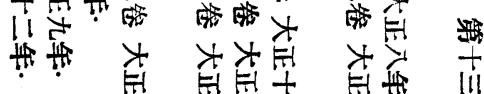

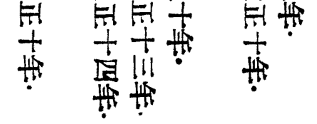

彞

㶌

水ナ腫、壇腫

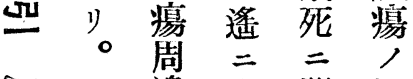
丑 啡

四 於 三留临 於。寻素異 速 局 并

所

反郎コ

鹤

異

要

”。

郎

概言著

シ 筋 明

云肏

人於

筋 学筋

肉出

內 毛 內

$=1=$

於 八於

テ 移 $\bar{~}$

反植

應㤀皆

變丑的

化重

$\overrightarrow{\text { 般 }}$

弱

二性二雉 究

》 $=$ 》落 $\equiv$ 壇邊移肉》 殖 緣 植 腫 テ 七二腫, 、 於陽同全 腫厂增種只 陽 浸 殖殊 不 人润 性 性 樣 異能 莊或式種 異破異族》。 二嘪 二 植 万性 原 ○一。於 䬣 䈃 䬣 天 筋畋皮各 肉 $尹$ 下培 內 基 二 地 二底 於 八下点 主 シ 、名 年主移 シ 腹 卜 植 テ 脫 三 垻 實 $=$ 殖 質向膨二 性 一 對 $=ル$ 性 富モ或ル ミ 八 八 特 皮椆整異 等性虽 腹于筋有 腔”肉呙。 向 首於 广 $\bar{~}$

粘主 